\title{
Research
}

\section{Adaptive Harvesting in a Multiple-Species Coral-Reef Food Web}

\author{
Daniel B. Kramer $^{1}$
}

\begin{abstract}
The utility of traditional bio-economic harvest models suffers from their dependence on two commonly used approaches. First, optimization is often assumed for harvester behavior despite system complexity and the often neglected costs associated with information gathering and deliberation. Second, ecosystem interactions are infrequently modeled despite a growing awareness that these interactions are important. This paper develops a simulation model to examine the consequences of harvesting at two trophic levels in a coral-reef food web. The model assumes adaptive rather than optimizing behavior among fishermen. The consequences of changing economic, biological, and social parameters are examined using resilience as an evaluative framework. Three general conclusions are reached. First, the simulated ecosystem is sensitive to small changes in economic, biological, and social parameters. Second, threshold effects are common. Third, as compared to results typical of traditional single-species optimization models, some results are counter-intuitive. Benefits of this approach are that the model affirms and adds to the results of traditional bio-economic harvest models, is empirically operational, and provides a richer selection of policy alternatives. Finally, the analysis of trade-offs in terms of resilience provides a useful evaluative framework for multiple-species harvest models.
\end{abstract}

Key Words: fisheries; resource economics; coral reefs; resilience; adaptive behavior; food web; simulation

\section{INTRODUCTION}

Much progress has been made in resource economics since the seminal works of Hotelling (1931), Gordon (1954), Scott (1955), and Clark (1976). The sophistication of bio-economic harvest models has grown rapidly, although their policy impacts have been questioned (Wilen 2000). Although fisheries have received more scrutiny from modelers than most resources, global stocks continue to decrease (Myers and Worm 2003). Some suggest that fisheries management has been ineffective because of the focus on single-species harvest goals rather than on maintaining ecological function (Pikitch et al. 2004). Others contend that the reliance of resource models on the unrealistic assumption of optimizing human behavior perpetuates poor descriptions of the interactions between ecology and society and thus leads to unrealistic or poor management prescriptions (Van Den Bergh et al. 2000).
In this study, I developed a simulation harvest model in response to these critiques. I examined the consequences of adaptive harvesting of multiple species at two trophic levels in a simple coral-reef food web and of changing economic, biological, and social parameters using the framework of resilience to evaluate the desirability of simulated outcomes.

\section{Ecological simplification}

Species of interest to humans do not exist in isolation but are part of complex ecosystems. The harvest of a single species affects other species and ecological processes. This may create positive and negative feedback loops that affect the target species and lead to great management uncertainty.

The few bio-economic modeling studies that examine the effects of harvesting in multiplespecies environments often limit their analyses to predator-prey relationships. Even fewer studies 
consider harvesting competitive or mutualistic species. Harvest models of more than two species are rarer still and provide greater analytical difficulties. May et al. (1979) provided an early analysis of harvesting among three species in various predator-prey relationships that found evidence of multiple equilibria and catastrophic behavior. Finoff and Tschirhart developed a general equilibrium ecosystem model to examine the effects of harvesting a single species in an eight-species Alaskan marine ecosystem (2003a) and to study the effects of the pollock harvest on endangered sea lion populations $(2003 \mathrm{~b})$. At present, the consensus seems to be that fisheries conservation objectives cannot be met without accounting for the dynamics of entire ecosystems (Gislason et al. 2002).

\section{Behavioral simplification}

A second critique of renewable-resource harvest models is the frequent use of optimization frameworks to simulate human behavior. Often, modelers develop prescriptions that may have little relevance to the management of real ecosystems. Simon's "bounded rationality" (1955) and Kahneman and Tversky's "prospect theory" (1979) were early efforts that recognized the limits to human cognition and suggested the use of models based on simple heuristics. Behavioral economics and evolutionary game theory also stress the prevalence of adaptive behavior.

Here I present a model of adaptive behavior based on evolutionary processes. Agents with strategies that yield outcomes that are worse on average switch to successful strategies, thereby increasing their numbers. I used replicator dynamics (Taylor and Jonker 1978) to model the evolution of harvest strategies in a community as a function of changing fishing profits.

Other studies have examined the resource management implications of using adaptive models of human behavior. Jager et al. (2000) used a multiple-agent model to study the emergence of macro-processes from micro-decisions in the context of a commons dilemma. Anderies (2000) revisited a model of resource extraction on Easter Island that was first presented by Brander and Taylor (1998), who used an adaptive rather than an optimization behavioral model. Sethi and Somanathan (1996) used replicator dynamics to model the evolution of strategies between cooperators, defectors, and enforcers over a single renewable resource. They concluded that the advantage of using an evolutionary model of human behavior is that it makes theory "empirically operational."

The two common assumptions in bio-economic modeling, single-species systems and optimizing human behavior, are related. Once it is assumed that optimization is the most appropriate model of human behavior, there is a limit to the complexity that can be assumed for the harvesting environment if analytical results are desired. In this study, maximizing the returns for a fishery among a coralreef food web becomes a difficult nonlinear mathematical problem of finding the optimal harvest level with four state variables and two control variables.

Optimization methods provide a limited evaluative framework for complex ecosystems because it is not clear what should be optimized. Optimizing profits or yields seems insufficient given multiple species with direct and indirect values. Resilience provides an alternate evaluative framework. Resilience is the ability of systems to absorb shocks, to resist sudden shifts to undesirable states, and to regenerate. There is currently no generally accepted quantitative measure of resilience (Allen et al. 2005, Stow et al. 2007).

\section{Coral reefs}

Coral reefs provide a well-studied example of a complex ecosystem with nonlinear interactions and thus the potential for catastrophic results because of human mismanagement. Anthropogenic stresses like climate change, pollution, sedimentation, and the overexploitation of fish stocks are the primary causes of reef degradation. Given the importance of coral reefs as marine biodiversity hotspots, as natural shoreline buffers, and as major tourist destinations, scientists have increasingly studied the community dynamics of coral reefs (Roberts et al. 2002). Examples of large exogenous shocks to reefs include the 1997 and 1998 El Niño and La Niña events, the outbreak of the crown-of-thorns starfish (Acanthaster planci) in the Great Barrier Reef, and the loss to disease of the herbivorous long-spined sea urchin (Diadema antillarum) in the Caribbean. There is disagreement among reef scientists as to whether reef dynamics are primarily driven by nutrient flows or by herbivory, i.e., by bottom-up or top-down processes (Miller et al. 1999). 
In the next section, I present a simplified reef model. The results of several sensitivity analyses follow. These results are compared with the current state of knowledge in reef ecology and management in the discussion section. I conclude by discussing policy implications.

\section{METHODS}

\section{Modeling algae and corals}

Reefs have shown a tendency to exist in alternate coral- or algae-dominated states. Examples are found in the Caribbean (Hughes 1994, Ostrander et al. 2000) and the Pacific (Done 1992). These shifts, driven partly by the competition for light and space between corals and algae, are persistent (Williams and Polunin 2001). Several mechanisms have been proposed to explain the competitive interaction between coral and algae. Algae can inhibit coral growth, recruitment, and settlement by shading, abrasion, alleopathic chemical defenses, and overgrowth. Coral can inhibit algae growth by shading, stinging, alleopathic chemical defenses, the occupation of space, mucus secretion, and overgrowth (McCook et al. 2001).

The competitive interaction between coral and algae depends on the structure of the algal community. The four algal functional groups are symbiotic, turf, fleshy macro-, and calcareous algae. The growth of fleshy macro-algae in particular has been shown through field and lab studies to reduce coral cover because of lower growth, reduced fecundity, and increased tissue mortality (Tanner 1995). Coral and macro-algae interactions are common (Lirman 2001). Although there is strong empirical evidence for the competition between coral and algae, there are few models describing these dynamics.

Here algae and coral were modeled using a LotkaVolterra model of intraspecific and interspecific competition. I adopted the usual assumptions of population, temporal, and spatial homogeneity with no migration. This model differs from the classical model, however, in postulating a nonlinear competitive interaction of algae on coral.

Algae grow according to a modified logistic growth equation, $\frac{d A}{d t}=r_{A} A[t]\left(\frac{K_{A}-A[t]-a_{A C} C[t]}{K_{A}}\right)-a_{A H} H[t] A[t]$

where $A(t)$ is the proportion of algal cover at time $t$, $r_{\mathrm{A}}$ is the intrinsic growth rate of algae, $K_{\mathrm{A}}$ is the carrying capacity of algae in percent of algal cover, $a_{\mathrm{AC}}$ is the competition coefficient of coral on algae, $C(t)$ is the proportion of coral cover, $H(t)$ is the herbivore density in kilograms per square kilometer, and $a_{\mathrm{AH}}$ is the interaction term between herbivores and algae. A simple linear competition coefficient of coral on algae and herbivores on algae was used in Eq. 1 because of the absence of evidence of more complex relationships. The model treats the effect of coral on algae differently than the effect of herbivores on algae by incorporating the competition coefficient, $a_{\mathrm{AC}}$, into the first term. By doing so, the competition for light and space is implicitly modeled. The competition coefficient, $a_{\mathrm{AC}}$, measures interspecific competition relative to intraspecific competition by indicating how many units of coral are equivalent to one unit of algae in terms of their resource use. If the effects of coral and herbivores are zero, the growth equation reduces to a simple logistic growth function with only intraspecific competition. Assuming no herbivore effect, setting the growth equation equal to zero and solving for $C(t)$ produces the equation for the algal nullcline,

$$
C[t]=\left(\frac{K_{A}-A[t]}{a_{A C}}\right)
$$

In the coral growth equation,

$$
\frac{d C}{d t}=r_{C} C[t]\left(\frac{K_{C}-C[t]-a_{C A}\left(\frac{A[t]^{\text {Sope }}}{A[t]^{\text {Soppe }}+H A^{\text {Slope }}}\right)}{K_{C}}\right)
$$

$r_{\mathrm{C}}$ is the intrinsic growth rate of coral, $K_{\mathrm{C}}$ is the carrying capacity of coral as the proportion of sea floor coverage, and $a_{\mathrm{CA}}$ is the competition 
coefficient of algae on coral. The last term in the numerator is a sigmoidal Hill function. The shape of this function is controlled by two parameters. Slope is the steepness of the curve at the inflection point, a measure of the effect on coral as the community structure of algae shifts. $H A$ is the half saturation constant or, in this case, the amount of algal cover at which coral cover is at $50 \%$ of its carrying capacity. If algal cover equals zero, the third term equals zero, and coral grows according to the unmodified logistic growth equation. Setting the coral growth equation equal to zero and solving for $C(t)$ produces the equation for the coral nullcline,

$$
C[t]=K_{C}-a_{C A}\left(\frac{A[t]^{\text {Slope }}}{A[t]^{\text {Slope }}+H A^{\text {Sbpe }}}\right)
$$

The nonlinear shape of the coral nullcline (Fig. 1) results from the assumption of a nonlinear competition coefficient of algae on coral and is important in generating alternate stable states. Some justification for this assumption is warranted. Observational studies have shown that, as algal cover and biomass increase, the composition of the algal community shifts from turf algae to fleshy, upright macro-algae (Done 1992). This shift causes a dramatic reduction in coral cover for three reasons. First, macro-algae are less palatable to herbivorous reef fish and therefore continue to grow and outcompete corals in the manner of a positive feedback loop, especially under conditions of low herbivory (Scheffer et al. 2001). Second, macro-algae, unlike turf algae, have a detrimental shading effect on coral and can prevent larval settlement, which causes a rapid reduction in coral cover at some specified threshold (Connell et al. 1997), postulated here to occur in the neighborhood of $H A$. Finally, macroalgae can brush against corals, abrading tissue and spreading disease (Nugues et al. 2004).

\section{Modeling herbivorous and piscivorous fish}

The abundance of herbivorous fish, kept in check by piscivorous fish, is the main constraint to the stock of algae biomass on coral reefs. The growth equation for herbivorous fish, $\frac{d H}{d t}=a_{H A} H[t] A[t]-a_{H H H} H[t]-a_{H P} H[t] E[t]-p o p S_{H} a_{H M} E_{H} H[t]$

includes the parameters $a_{\mathrm{HA}}$ for the interaction coefficient of algae on herbivores, $a_{\mathrm{HH}}$ for the density-dependent coefficient for herbivores, $a_{\mathrm{HP}}$ for the interaction coefficient of piscivores on herbivores, pop for the total population of fishers per square kilometer, $S_{H}$ for the proportion of fishers who harvest herbivores, $a_{\mathrm{HM}}$ for the catch efficiency of fishers with a given technology, and $E_{\mathrm{H}}$ for the fishing effort in hours fished per day.

Piscivore growth is modeled by

$$
\frac{d P}{d t}=a_{P H} F[t] H[t]-a_{P P} F[t]-p o p S_{P} a_{Z M} E_{P} F[t]
$$

using $a_{\mathrm{PH}}$ as the interaction term of herbivores on piscivores, $S_{\mathrm{P}}$ as the proportion of fishers who harvested piscivores, $a_{\mathrm{PM}}$ as the catch efficiency of fishers of piscivore fish, $E_{\mathrm{P}}$ as the fishing effort of fishers who harvested piscivores, and $a_{\mathrm{PP}}$ as the density-dependent coefficient for piscivores.

\section{Modeling adaptive harvesters}

The artisanal reef fishing communities found in the Indo-Pacific, East Africa, and the Caribbean can cause significant changes on local reef ecosystems, including increases in algae cover (Hawkins and Roberts 2004), decreased abundance of target species (Jennings and Polunin 1997), and alterations in community structure (Dulvy et al. 2004). These effects depend on community composition, the extent of nutrification, habitat structure, physical disturbance, and oceanographic conditions.

Jennings and Polunin (1997) suggested that artisanal fishers shift their attention from depleted fish stocks to healthy fish stocks. This study used a model that simulates this adaptive approach to harvesting. The populations of fishers who harvest herbivores and piscivores change as each group compares its pay off to a community mean. A strategy that yields an above-average pay off leads to a greater proportion of that type of fishers in the population and vice versa. The replicator dynamics are defined as follows: 
Fig. 1. Algal and coral nullclines produce alternate stable states. The arrowed lines represent different sample trajectories based on different initial conditions. The dashed line, the separatix, divides the phase plane into two basins of attraction.

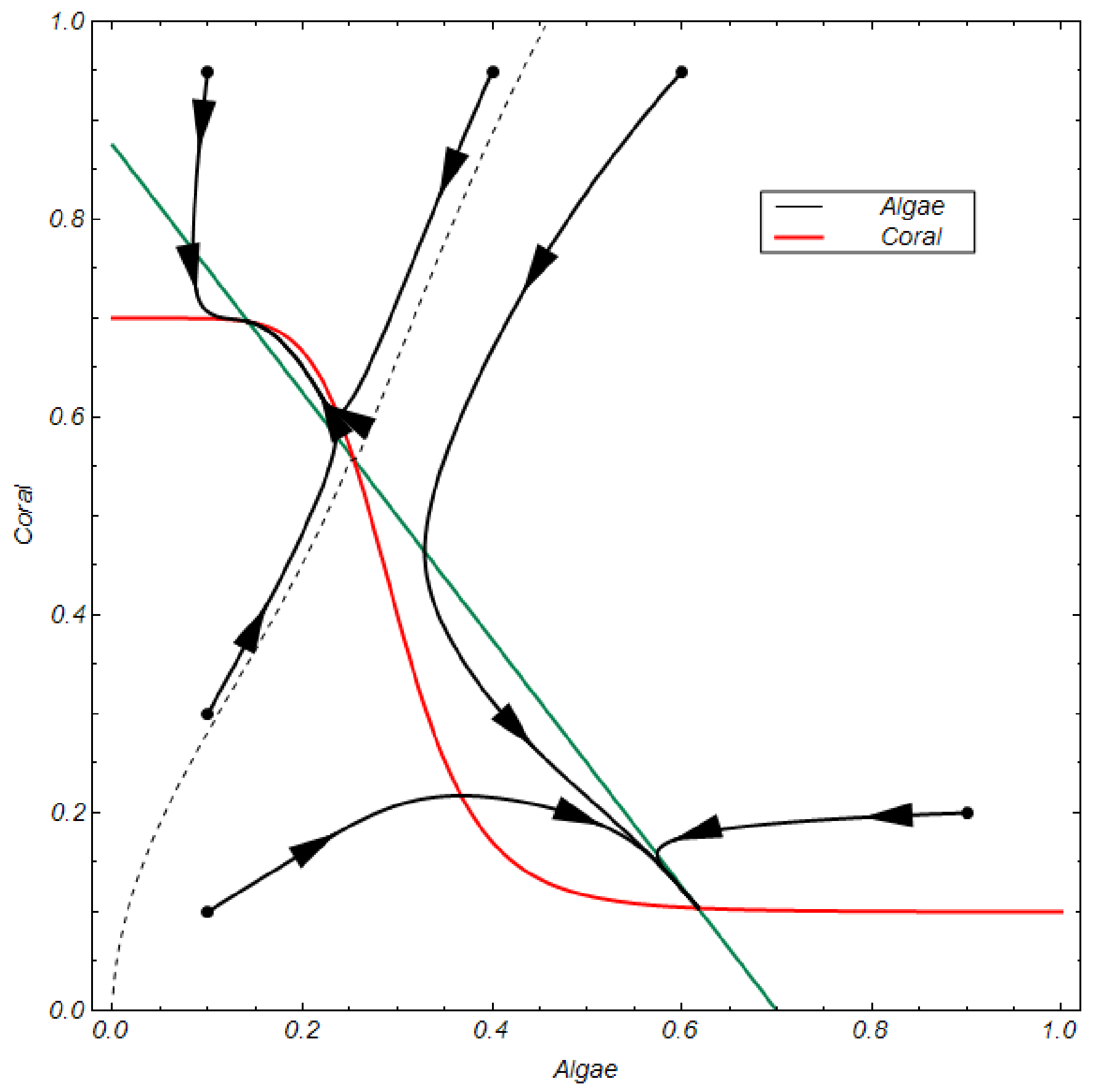




$$
\begin{aligned}
& \frac{d S_{V}}{d}=s c S_{H}[t]\left(\frac{\pi_{H}-\bar{\pi}}{\pi}\right) \\
& \frac{d S^{d}}{d}=\operatorname{scS}_{P}[t]\left(\frac{\pi_{P}-\bar{\pi}}{\bar{\pi}}\right)
\end{aligned}
$$

where the parameter $s c$ controls the speed at which the fishers switch between fish populations. Switching may not be instantaneous because of sunk fishing costs, an affinity for the status quo among fishers, or barriers to information flow. The magnitude of the switch depends on the magnitude of the profit differential.

The profits from fishing herbivorous and piscivorous reef fish are $\pi_{\mathrm{H}}$ and $\pi_{\mathrm{P}}$, respectively, in the following equations:

$$
\begin{aligned}
& \pi_{H}=E_{H} a_{H M} H[t]\left(\operatorname{Price} e_{H}-\frac{\operatorname{cost}_{H}}{H[t]}\right) \\
& \pi_{P}=E_{P} a_{B M}\left[[t]\left(\operatorname{Pr} i c e_{P}-\frac{\operatorname{Cost}_{H}}{P[t]}\right)\right.
\end{aligned}
$$

Price $_{H}$, Price $_{P}$, Cost $_{H}$, and Cost $_{P}$ are the per kilogram prices and costs for harvesting reef fish. Profits decrease as fish populations decrease because of the cost function. Mean profits are designated as $\pi$ topped by a bar and expressed as follows:

$$
\bar{\pi}=S_{H} \pi_{H}+S_{P} \pi_{P}
$$

Model parameters were based on estimates of mean biomass, consumption, and competition effects for reef systems under a variety of conditions, including different community structures, fishing intensities, and the year of estimate (Table 1). It is hoped that sampling from several empirical studies yielded mean parameter values that are biologically realistic and typical (Table 2). Initial conditions for all human, algae, coral, and fish populations are presented in Table 3. The biomass of algae and coral was converted to the proportion of the sea floor covered by each using a simple linear estimation.

Simulation outcomes were evaluated in terms of their resilience. Resilience is an attribute of states within systems, not of the systems themselves. Because some states, such as the coral-dominated state in a reef ecosystem, are preferred, society is concerned with maintaining their resilience. I measured the resilience of the coral-dominated state in each simulation using two methods. First, I measured resilience as the size of the basin of attraction of the coral-dominated state as a proportion of the plane of the coral/algae phase. This was possible because the phase plane is bound by values that range from zero to 1 because of the definition of the coral- and algae-state variables as the proportion of sea floor covered. The second measure of resilience, which also ranged from zero to 1, is the minimum Euclidean distance from the resulting coral-dominated equilibrium state to the boundary of its domain of attraction in the plane of the coral/algae phase (Anderies et al. 2002). Therefore, when simulations resulted in an algaedominated state, this measure of resilience was zero. The first measure does not depend on a final equilibrium state but rather on system parameters. It is a more finely tuned measure of resilience. This might be important when changes in parameters do little to change the minimum Euclidean distance but dramatically change the shape and size of the basin of attraction. The second measure is more conservative because it represents the minimum perturbation required to induce a state shift from an equilibrium state.

I first examined the generation of alternate stable states using only the coral and algae competition model. I then evaluated outcomes relative to the baseline simulation for the full reef model because of changes in economic, biological, and social parameters. Each simulation ran for a period of 20 yr. The simulation was written in Mathematica (Wolfram Inc., version 6.0.0, 2007). 
Table 1. Values used to derive parameters for baseline model.

\begin{tabular}{|c|c|c|c|c|}
\hline Measure & Description & Average value & Units & Source \\
\hline Algae & Average algae biomass & $100,000.0$ & $\mathrm{~kg} / \mathrm{km}^{2}$ & $\begin{array}{l}\text { Polovina (1984), Hughes } \\
\text { et al. (1987), McClanahan } \\
(1992,1995), \text { Polunin } \\
(1996)\end{array}$ \\
\hline Coral & Average coral biomass & $45,000.0$ & $\mathrm{~kg} / \mathrm{km}^{2}$ & McClanahan (1995) \\
\hline Fish growth & Average reef fish growth & 60.0 & $\mathrm{~kg} \cdot \mathrm{km}^{-2} \cdot \mathrm{d}^{-1}$ & $\begin{array}{l}\text { Odum and Odum (1955), } \\
\text { Lewis (1981), Edmunds } \\
\text { and Spencer (1986), } \\
\text { McClanahan (1995), } \\
\text { Polunin (1996) }\end{array}$ \\
\hline Herbivore growth & $\begin{array}{l}\text { Herbivorous fish growth } \\
\text { resulting from algae } \\
\text { consumption }\end{array}$ & 40.0 & $\mathrm{~kg} \cdot \mathrm{km}^{-2} \cdot \mathrm{d}^{-1}$ & McClanahan (1992) \\
\hline Piscivore growth & $\begin{array}{l}\text { Piscivorous fish growth } \\
\text { resulting from } \\
\text { herbivorous fish } \\
\text { consumption }\end{array}$ & 20.0 & $\mathrm{~kg} \cdot \mathrm{km}^{-2} \cdot \mathrm{d}^{-1}$ & $\begin{array}{l}\text { Polunin (1996), } \\
\text { McClanahan (1995) }\end{array}$ \\
\hline $\begin{array}{l}\text { Piscivore density } \\
\text { dependence }\end{array}$ & $\begin{array}{l}\text { Density dependent effect } \\
\text { of piscivores on } \\
\text { piscivores }\end{array}$ & 9.8 & $\mathrm{~kg} \cdot \mathrm{km}^{-2} \cdot \mathrm{d}^{-1}$ & $\begin{array}{l}\text { Polunin (1996), } \\
\text { McClanahan (1995) }\end{array}$ \\
\hline Algae growth & $\begin{array}{l}\text { Average algae growth per } \\
\text { day }\end{array}$ & $10,000.0$ & $\mathrm{~kg} \cdot \mathrm{km}^{-2} \cdot \mathrm{d}^{-1}$ & $\begin{array}{l}\text { Wanders (1976), Atkinson } \\
\text { and Grigg (1984), Berner } \\
\text { (1990), McClanahan } \\
\text { (1995) Polunin (1996) }\end{array}$ \\
\hline Coral growth & $\begin{array}{l}\text { Average coral growth per } \\
\text { day }\end{array}$ & 6000.0 & $\mathrm{~kg} \cdot \mathrm{km}^{-2} \cdot \mathrm{d}^{-1}$ & $\begin{array}{l}\text { Wanders (1976), Atkinson } \\
\text { and Grigg (1984), Berner } \\
\text { (1990), McClanahan } \\
\text { (1995), Polunin (1996) }\end{array}$ \\
\hline $\begin{array}{l}\text { Algae on } \\
\text { coral }\end{array}$ & Effect of algae on coral & 6000.0 & $\mathrm{~kg} \cdot \mathrm{km}^{-2} \cdot \mathrm{d}^{-1}$ & $\begin{array}{l}\text { Atkinson and Grigg } \\
\text { (1984), McClanahan } \\
\text { (1995) }\end{array}$ \\
\hline $\begin{array}{l}\text { Coral on } \\
\text { algae }\end{array}$ & Effect of coral on algae & 3000.0 & $\mathrm{~kg} \cdot \mathrm{km}^{-2} \cdot \mathrm{d}^{-1}$ & \\
\hline $\begin{array}{l}\text { Herbivores } \\
\text { on algae }\end{array}$ & $\begin{array}{l}\text { Effect of herbivores on } \\
\text { algae }\end{array}$ & 7000.0 & $\mathrm{~kg} \cdot \mathrm{km}^{-2} \cdot \mathrm{d}^{-1}$ & $\begin{array}{l}\text { Polunin (1996), } \\
\text { McClanahan (1992) }\end{array}$ \\
\hline Piscivores on herbivores & $\begin{array}{l}\text { Effect of piscivores on } \\
\text { herbivores }\end{array}$ & 30.0 & $\mathrm{~kg} \cdot \mathrm{km}^{-2} \cdot \mathrm{d}^{-1}$ & $\begin{array}{l}\text { Polunin (1996), } \\
\text { McClanahan (1992) }\end{array}$ \\
\hline Humans on herbivores & $\begin{array}{l}\text { Effect of humans on } \\
\text { herbivorous fish }\end{array}$ & 2.0 & $\mathrm{~kg} \cdot \mathrm{km}^{-2} \cdot$ person $^{-1} \cdot \mathrm{d}^{-1}$ & $\begin{array}{l}\text { Jennings and Polunin } \\
\text { (1996), Polunin and } \\
\text { Klumpp (1989), Dalzell } \\
(1996)\end{array}$ \\
\hline Humans on piscivores & $\begin{array}{l}\text { Effect of humans on } \\
\text { piscivorous fish }\end{array}$ & 3.0 & $\mathrm{~kg} \cdot \mathrm{km}^{-2} \cdot$ person $^{-1} \cdot \mathrm{d}^{-1}$ & $\begin{array}{l}\text { Jennings and Polunin } \\
\text { (1996), Polunin and } \\
\text { Klumpp (1989), Dalzell } \\
(1996)\end{array}$ \\
\hline
\end{tabular}


Table 2. Derived parameter values used in baseline model.

\begin{tabular}{|c|c|c|c|c|}
\hline Parameter & Description & Value & Units & Source \\
\hline$A(0)$ & $\begin{array}{l}\text { Initial algae } \\
\text { cover as } \\
\text { proportion of } \\
\text { sea floor }\end{array}$ & 0.3 & $\begin{array}{l}\text { Proportion of } \\
\text { sea floor }\end{array}$ & \\
\hline$C(0)$ & $\begin{array}{l}\text { Initial coral } \\
\text { cover as } \\
\text { proportion of } \\
\text { sea floor }\end{array}$ & 0.3 & $\begin{array}{l}\text { Proportion of } \\
\text { sea floor }\end{array}$ & \\
\hline$H(0)$ & $\begin{array}{l}\text { Initial herbi- } \\
\text { vorous fish } \\
\text { density }\end{array}$ & 2100.0 & $\mathrm{~kg} / \mathrm{km}^{2}$ & $\begin{array}{l}\text { Polunin (1996), } \\
\text { McClanahan } \\
\text { (1992, 1995), } \\
\text { McClanahan et } \\
\text { al. (1996) }\end{array}$ \\
\hline$P(0)$ & $\begin{array}{l}\text { Initial pisci- } \\
\text { vorous fish } \\
\text { density }\end{array}$ & 1400.0 & $\mathrm{~kg} / \mathrm{km}^{2}$ & $\begin{array}{l}\text { Polunin (1996), } \\
\text { McClanahan } \\
(1992,1995) \text {, } \\
\text { McClanahan et } \\
\text { al. (1996) }\end{array}$ \\
\hline$S_{\mathrm{H}}(0)$ & $\begin{array}{l}\text { Initial prop- } \\
\text { ortion of } \\
\text { fishers in } \\
\text { population } \\
\text { harvesting } \\
\text { herbivorous } \\
\text { fish }\end{array}$ & 0.5 & $\begin{array}{l}\text { Proportion of } \\
\text { population }\end{array}$ & \\
\hline$S_{\mathrm{P}}(0)$ & $\begin{array}{l}\text { Initial prop- } \\
\text { ortion of } \\
\text { fishers in } \\
\text { population } \\
\text { harvesting } \\
\text { piscivorous }\end{array}$ & 0.5 & $\begin{array}{l}\text { Proportion of } \\
\text { population }\end{array}$ & \\
\hline Pop & $\begin{array}{l}\text { Total popul- } \\
\text { ation of } \\
\text { fishers }\end{array}$ & 50.0 & fishers $/ \mathrm{km}^{2}$ & \\
\hline$E_{\mathrm{H}}$ & $\begin{array}{l}\text { Effort level } \\
\text { of fishers } \\
\text { harvesting } \\
\text { herbivorous } \\
\text { fish }\end{array}$ & 2.0 & $\mathrm{~h} / \mathrm{d}$ & $\begin{array}{l}\text { Jennings and } \\
\text { Polunin (1996) }\end{array}$ \\
\hline$E_{\mathrm{P}}$ & $\begin{array}{l}\text { Effort level } \\
\text { of fishers } \\
\text { harvesting } \\
\text { piscivorous } \\
\text { fish }\end{array}$ & 2.0 & $\mathrm{~h} / \mathrm{d}$ & $\begin{array}{l}\text { Jennings and } \\
\text { Polunin (1996) }\end{array}$ \\
\hline Price $_{\mathrm{H}}$ & $\begin{array}{l}\text { Price/kg for } \\
\text { herbivorous } \\
\text { fish }\end{array}$ & 2.0 & U.S. \$ & \\
\hline
\end{tabular}




\begin{tabular}{|c|c|c|c|}
\hline Price $_{\mathrm{P}}$ & $\begin{array}{l}\text { Price } / \mathrm{kg} \text { for } \\
\text { piscivorous } \\
\text { fish }\end{array}$ & 2.0 & U.S. \$ \\
\hline $\operatorname{Cost}_{\mathrm{H}}$ & $\begin{array}{l}\text { Cost per } \\
\text { unit of } \\
\text { effort per } \\
\text { kilogram of } \\
\text { herbivorous } \\
\text { fish }\end{array}$ & 1.0 & U.S. \$ \\
\hline $\operatorname{Cost}_{\mathrm{P}}$ & $\begin{array}{l}\text { Cost per } \\
\text { unit of } \\
\text { effort per } \\
\text { kilogram of } \\
\text { piscivorous } \\
\text { fish }\end{array}$ & 1.0 & U.S. \$ \\
\hline
\end{tabular}

\section{RESULTS}

The coral and algal nullclines based on baseline parameter values cross three times and represent three interior equilibria (Fig. 1). Two of these equilibria are stable, as indicated by several representative trajectories. The coral- and algaedominated stable states each lie within their basins of attraction, which are divided by the separatix. Thus, initial conditions are important in explaining the long-term steady state of this ecosystem.

I conducted sensitivity analyses to evaluate the qualitative effects of changes in model parameters. Increasing the carrying capacity of algae, $K_{\mathrm{A}}$, increases the equilibrium concentrations of algae at both stable equilibria as the algal nullcline shifts outward. Eventually, the basin of attraction for the coral-dominated state disappears. On the other hand, as $K_{\mathrm{C}}$ increases and the coral nullcline shifts outward, equilibrium coral concentrations increase at both stable equilibria until there is only one stable high-coral-cover equilibrium.

As the competition coefficient of coral on algae increases, the coral-dominated equilibrium shows a reduction in algae cover until the high algal state is no longer stable. Similarly, increasing $a_{\mathrm{CA}}$ lowers coral cover and raises algal cover at each stable equilibrium. Doing so, however, has a greater effect at the high algal equilibrium. As the intrinsic rate of growth for coral, $r_{\mathrm{C}}$, increases, the separatix bows inward toward the algal cover axis, effectively enlarging the basin of attraction of the coraldominated state.

Figure 2 plots the algal and coral nullplanes and the effect of increasing herbivory. As herbivory increases, the system shifts from one of alternate stable states to a single, coral-dominated equilibrium. Thus, bottom-up, e.g., intrinsic growth rates, and top-down, e.g., herbivory, processes affect the stability and state of this stylized coralreef ecosystem.

In the next several graphs, the simulated fish, coral, and algae populations are shown as parametric plots. Fisher populations are shown in time-series plots. Because fisher populations sum to one and are mirror images of each other, only the plots for fishers of herbivore fish are presented. Profit differentials between each type of fisher are also shown as time-series plots. Under baseline conditions, the fishers and fish populations (Figs. 3A,B), driven by predator-prey dynamics, differing catch efficiencies, and profits, experience damped oscillations. The larger oscillations in fisher populations continue because of relatively small oscillations in fish densities and profits (Figs. 3B, D). As might be expected, profit differentials narrow over time as fishers freely alternate between strategies based on profit incentives (Fig. 3D). The reef is in a coral-dominated state with $70 \%$ coral cover and roughly $15 \%$ algal cover (Figure $3 \mathrm{C}$ ). The basin of attraction of the coral-dominated state accounts for $79 \%$ of the plane of the coral/algae 
Table 3. Parameter values and initial conditions used in baseline model.

\begin{tabular}{|c|c|c|}
\hline Parameter & Description & Value \\
\hline$r_{\mathrm{A}}$ & $\begin{array}{l}\text { Algal intrinsic rate of } \\
\text { growth }\end{array}$ & 0.3 \\
\hline$K_{\mathrm{A}}$ & $\begin{array}{l}\text { Algal carrying capacity } \\
\text { as cover }\end{array}$ & 0.8 \\
\hline$a_{\mathrm{AC}}$ & $\begin{array}{l}\text { Competition coefficient } \\
\text { of coral on algae }\end{array}$ & 0.8 \\
\hline$a_{\mathrm{AH}}$ & $\begin{array}{l}\text { Interaction coefficient of } \\
\text { herbivorous fish on algae }\end{array}$ & 3.3E-05 \\
\hline$r_{\mathrm{C}}$ & $\begin{array}{l}\text { Coral intrinsic rate of } \\
\text { growth }\end{array}$ & 0.2 \\
\hline$K_{\mathrm{C}}$ & Coral carrying capacity & 0.7 \\
\hline$a_{\mathrm{CA}}$ & $\begin{array}{l}\text { Competition coefficient } \\
\text { of algae on coral }\end{array}$ & 0.6 \\
\hline Slope & Slope of the Hill function & 7.0 \\
\hline$H A$ & $\begin{array}{l}\text { Half saturation constant } \\
\text { of Hill function }\end{array}$ & 0.3 \\
\hline$a_{\mathrm{HA}}$ & $\begin{array}{l}\text { Interaction coefficient of } \\
\text { algae on herbivorous fish }\end{array}$ & 0.1 \\
\hline$a_{\mathrm{HP}}$ & $\begin{array}{l}\text { Interaction coefficient of } \\
\text { piscivorous fish on } \\
\text { herbivorous fish }\end{array}$ & $1.0 \mathrm{E}-05$ \\
\hline$a_{\mathrm{HM}}$ & $\begin{array}{l}\text { Harvest catchability } \\
\text { coefficient of herbivorous } \\
\text { fish }\end{array}$ & $1.9 \mathrm{E}-05$ \\
\hline$a_{\mathrm{PP}}$ & $\begin{array}{l}\text { Density-dependent coefficient } \\
\text { of piscivorous fish }\end{array}$ & 7.0E-03 \\
\hline$a_{\mathrm{PH}}$ & $\begin{array}{l}\text { Interaction coefficient of } \\
\text { herbivorous fish on } \\
\text { piscivorous fish }\end{array}$ & $6.8 \mathrm{E}-06$ \\
\hline$a_{\mathrm{PM}}$ & $\begin{array}{l}\text { Harvest catchability } \\
\text { coefficient of piscivorous } \\
\text { fish }\end{array}$ & 4.3E-05 \\
\hline
\end{tabular}

phase, and the minimum Euclidean distance between the final equilibrium state and the boundary of the basin of attraction is 0.58 .

Three results are noteworthy when one type of fisher is eliminated (Fig. 4). First, predator-prey oscillations end earlier. Second, when the ecosystem faces only fishers who harvest herbivores, herbivore populations decrease slightly from the baseline and piscivore densities increase greatly (Fig. 4A). Ceasing the harvest of piscivores adequately compensates for the loss of their prey because of harvesting. However, when the ecosystem is subject to harvest only by fishers who 
Fig. 2. Algal and coral nullplanes and the role of herbivory.

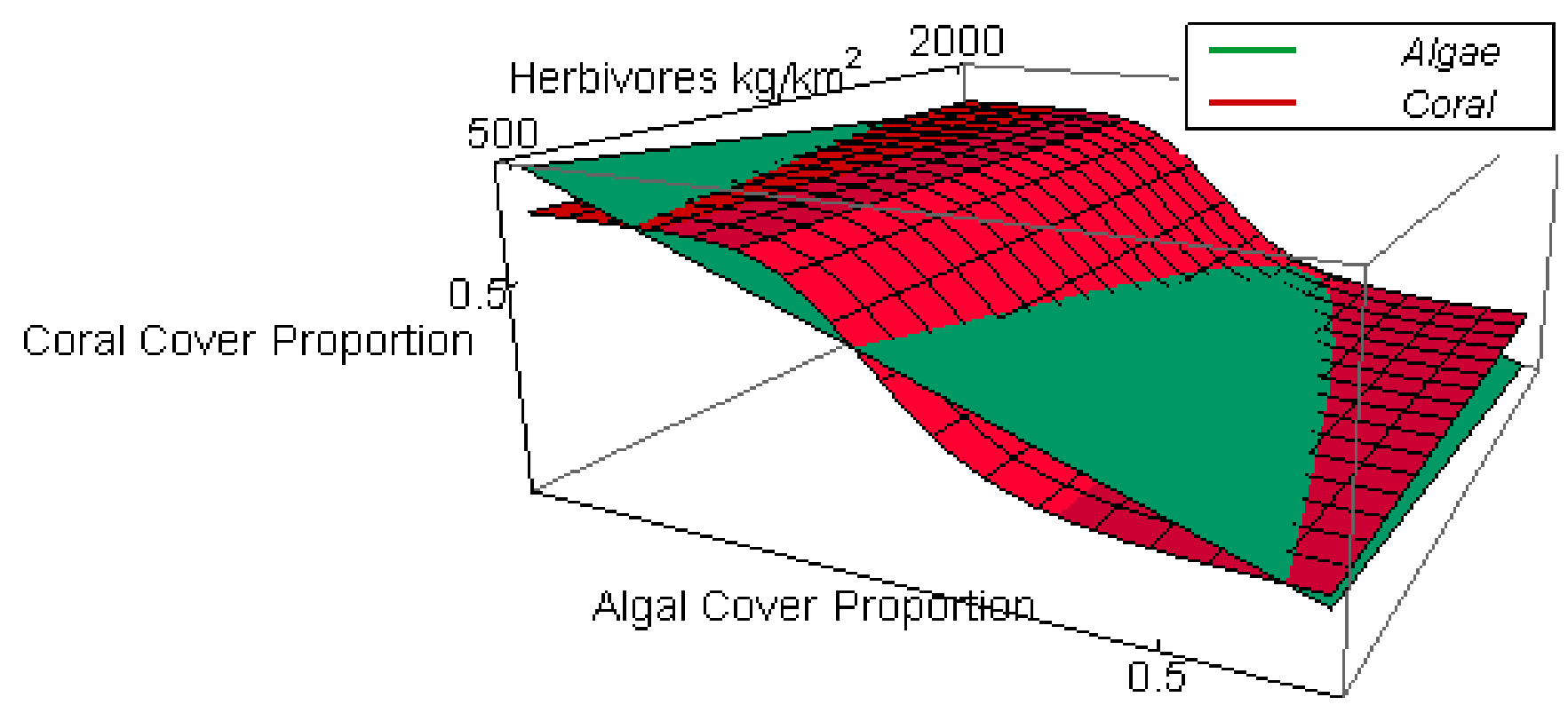

catch piscivores, herbivores increase slightly because of decreased predation pressure, and piscivore densities change little. Finally, only the algae-dominated state exists when only herbivorous fish are harvested (Fig. 4B). The values of the basin of attraction of the coral-dominated state under herbivore- and piscivore-only harvests are zero and $82 \%$, and the Euclidean distances are zero and 0.60, respectively.

Exogenous prices for herbivorous and piscivorous fish will vary because of changes in supply and demand. An increase in the price for herbivorous fish to U.S. $\$ 3.00 / \mathrm{kg}$ initially causes large oscillations in herbivore and piscivore densities (Fig. 5B). This coincides with oscillations in coral and algal cover (Fig. 5C). At U.S. \$3.50, herbivore and piscivore populations increase beyond their baseline oscillations. Also, the reef ecosystem switches from a coral- to an algae-dominated state. At U.S. \$3.00, the profit differential eventually stablizes to zero, whereas, at U.S. \$3.50, a profit differential is maintained because only fishers who harvest piscivores remain (Figs. 5A,D). The values of the basin of attraction of the coral-dominated state at U.S. $\$ 3.00$ and U.S. $\$ 3.50$ are 51 and $49 \%$, and the Euclidean distances are 0.42 and zero, respectively. Price increases for herbivorous fish erode resilience and increase the likelihood of an algae-dominated reef.

An increase in the price of piscivores to U.S. \$3.50/ $\mathrm{kg}$ causes a shift to a population of fishers who harvest only piscivores (Fig. 6A). This causes piscivore densities to drop slightly from the baseline and herbivores to increase slightly because of a decrease in predation (Fig. 6B). There is high coral in each scenario (Fig. 6C). Community structure and system dynamics are very resilient to increases in the price for piscivorous fish. Again, with positive populations of both types of fishers, profit differentials eventually stabilize at zero. At U.S. $\$ 3.50$, however, without fishers who harvest piscivores, a profit differential is maintained (Fig. $6 \mathrm{D})$. The coral-dominated basins of attraction account for 80 and $81 \%$ of the coral/algae phase plane at U.S. $\$ 2.50$ and U.S. \$3.50, and the Euclidean distances are 0.59 and 0.60 , respectively. 
Fig. 3. Baseline simulation time-series plots for fisher populations (3A) and profit differentials (3D), and parametric plots for fish (3B) and for coral and algae (3C). The dots represent initial conditions.

3A. Herbivore fishers
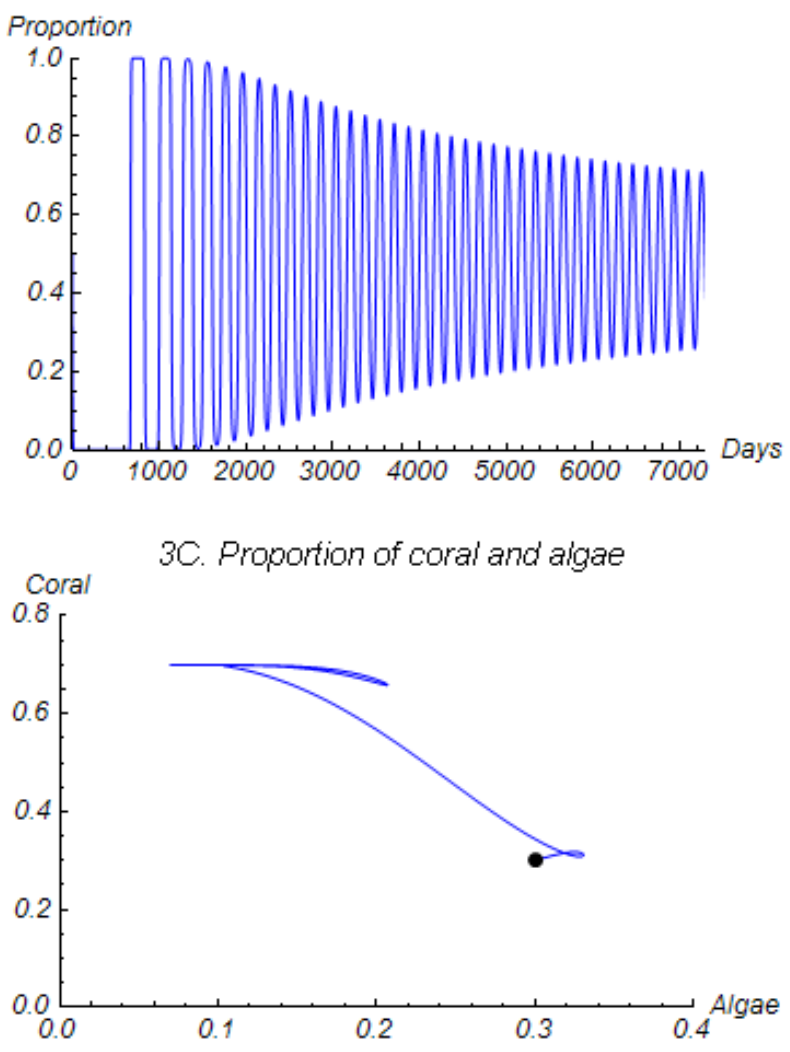

3B. Fish in kilograms per square kilometer

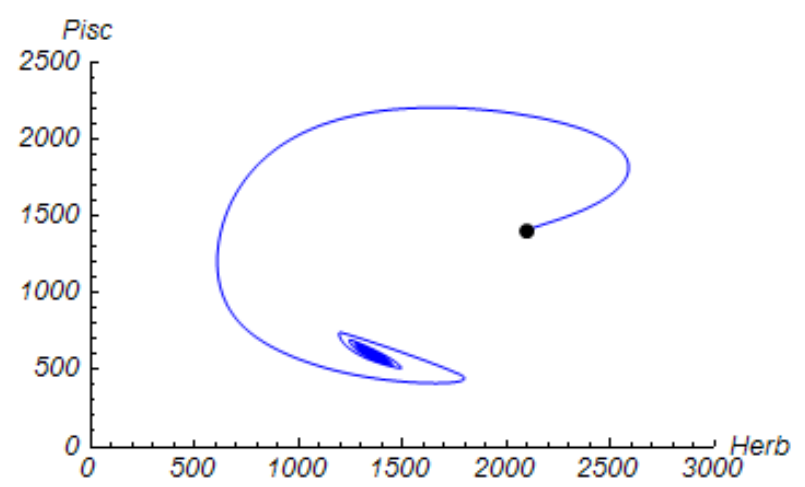

3D. Profit differential in U.S. \$ for hours fished

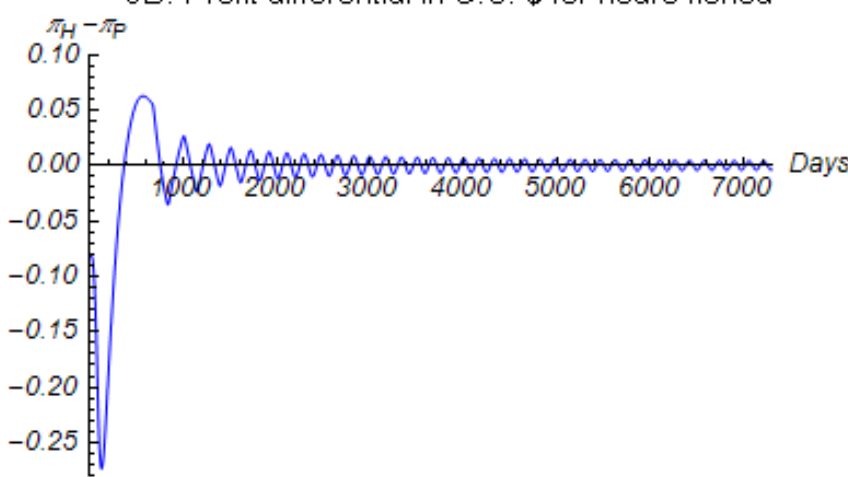

Increases in human populations can negatively affect resources. At a fisher density of $250 / \mathrm{km}^{2}$, both fish populations decrease compared to the baseline, with piscivores nearing extinction, algal cover increasing slightly, and coral cover remaining steady (Figs. 7B,C). Oscillations in fisher proportions are frequent until about $300 \mathrm{~d}$, when fishing shifts solely to herbivores (Fig. 7A). At 500 fishers, the system exhibits instability and state shifts. Fish and fisher populations oscillate (Figs. 7A,B). Fish populations oscillate at higher density levels than those of the baseline. Fisher populations oscillate before settling to roughly 70 and $30 \%$ for fishers who harvest herbivores and piscivores, respectively. Coral cover drops dramatically, and a high algal state dominates. An increase in algal primary productivity drives the fish populations to higher abundances despite the heavy harvesting pressure. At 250 fishers, only the coral-dominated state exists and is therefore completely resilient. At 500 fishers, only an algae-dominated state and a state characterized by stable limit cycles exist. Thus, at a population of 500, the reslience of the coraldominated state is zero. The profit differential goes to zero with both types of fishermen present and is positive when there are only fishers who harvest herbivores (Fig. 7D). 
Fig. 4. Simulation results with harvest by one type of fisher for fish (4A) and for coral and algae (4B). The dots represent initial conditions.
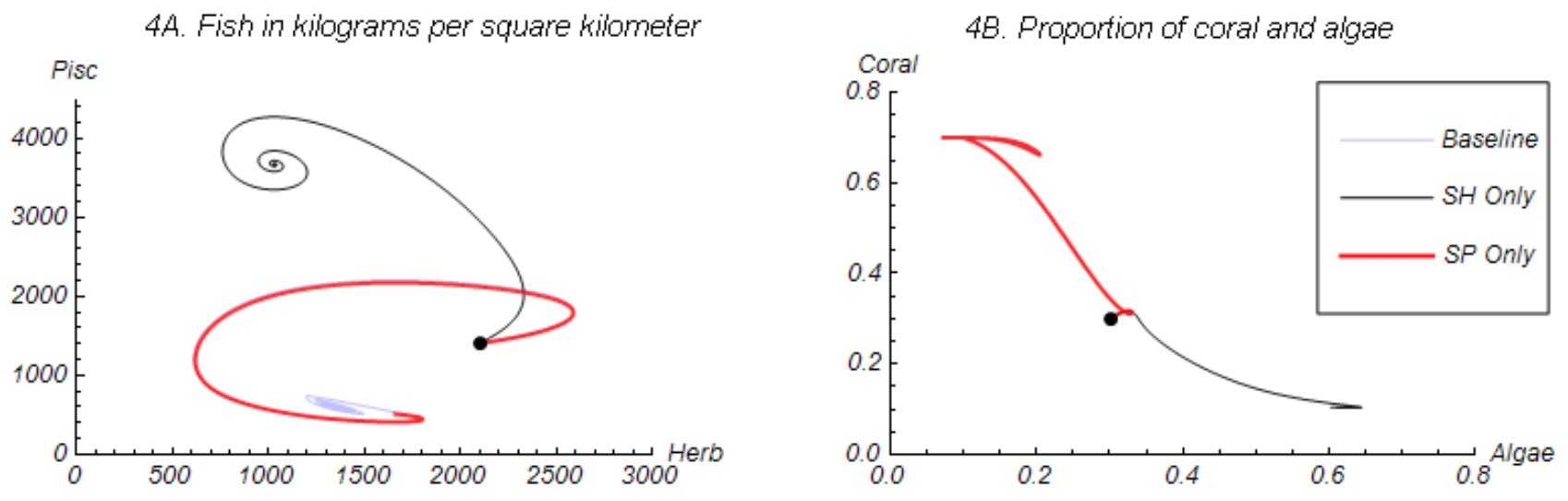

Figure 8 simulates changes in the number of hours fished per day to harvest herbivores. At $2.5 \mathrm{~h}$, there are large oscillations in the fish populations before they settle at population levels close to the baseline (Fig. 8B). At the end of $20 \mathrm{yr}$, more than $80 \%$ of fishers harvest herbivores (Fig. 8A). At $3.5 \mathrm{~h} / \mathrm{d}$, the system transitions to the algae-dominated stable state. Only piscivores are harvested. Again, the sudden switch to a state of high algal cover and the resulting loss of resiliency increase the populations of fish in the short term even with higher fishing effort among fishers who harvest herbivores. As fishing effort increases, resilience decreases. Increasing effort from 2.5 to $3.5 \mathrm{~h} / \mathrm{d}$ decreases the basin of attraction of the coral-dominated state from 70 to $48 \%$ of the plane of the coral/algae phase. Euclidian distances decrease from 0.53 to zero. At 2.5 and $4 \mathrm{~h} / \mathrm{d}$ of fishing effort to harvest piscivores, herbivore densities increase and piscivore densities decrease slightly from baseline levels, and oscillations continue (graphs not shown). Algal cover decreases slightly because of the increase in herbivore densities, and coral dominates under each scenario. Increasing fishing effort to havest piscivores increases resilience compared to baseline levels. The basins of attraction of the coraldominated state comprise 91 and $99 \%$ of the plane of the coral/algae phase, and the Euclidian distances are 0.60 and 0.67 for 2.5 and $4 \mathrm{~h}$ of effort, respectively.

The speed at which fishers adopt new strategies might vary because of the recognition of sunk costs or transaction costs, a preference for the status quo, or barriers to the flow of information because of weak social networks. As the reaction time of fishers slows from 1.0 to 0.20 to 0.05 , resiliency decreases. The basin of attraction of the coral-dominated state decreases from 79 to 63 to $59 \%$ of the plane of the coral/algae phase, and the Euclidean distance falls from 0.58 to 0.47 to 0.43 . Fish, coral, and algae populations as well as the profit differential exhibit larger oscillations at 0.20 than at 0.05 (Figs. 9B,C, D). It is clear that oscillations in profit differentials at a reaction time of 0.05 are driven by fish, coral, and algae oscillations. Also, at $6000 \mathrm{~d}$ there is a slight bump in algal cover, making the system more productive overall and eventually causing the proportion of fishers who harvest herbivores to rebound from near zero.

Figure 10 shows the graphical mapping of ecological states as a function of two parameters. The red-shaded area on the bottom and the greenshaded area at the top of each figure indicate coraldominated and algae-dominated equilibrium states, 
Fig. 5. Simulation results reflecting changes in the price of herbivorous fish showing time-series plots for fishers (5A) and profit differentials (5D), and parametric plots for fish (5B) and for coral and algae (5C). The dots represent initial conditions.

\section{A. Herbivore fishers}
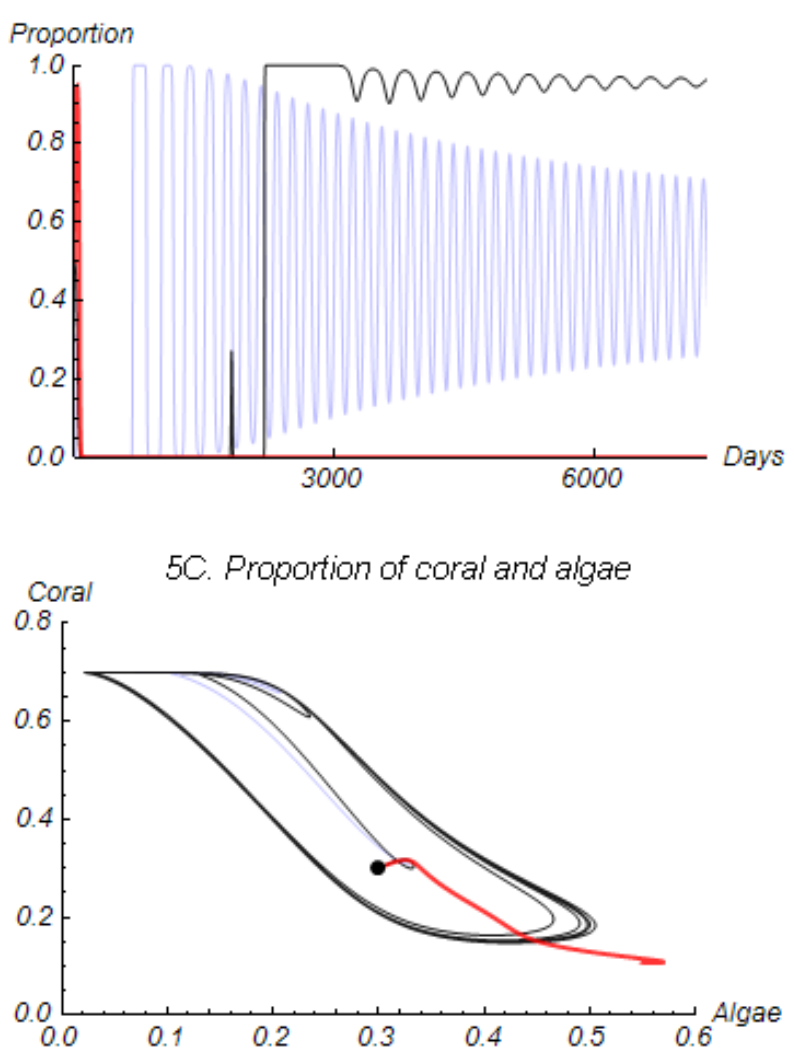

5B. Fish in kilograms per square kilometer

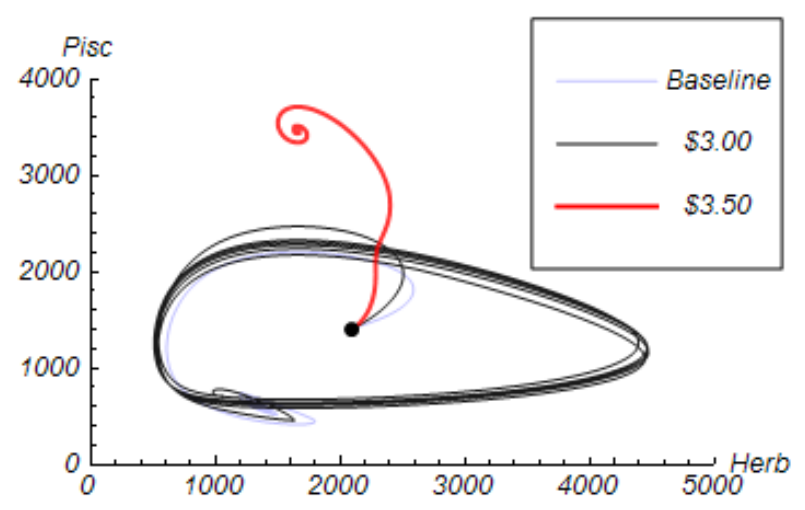

50. Profit differential in U.S. \$for hours fished

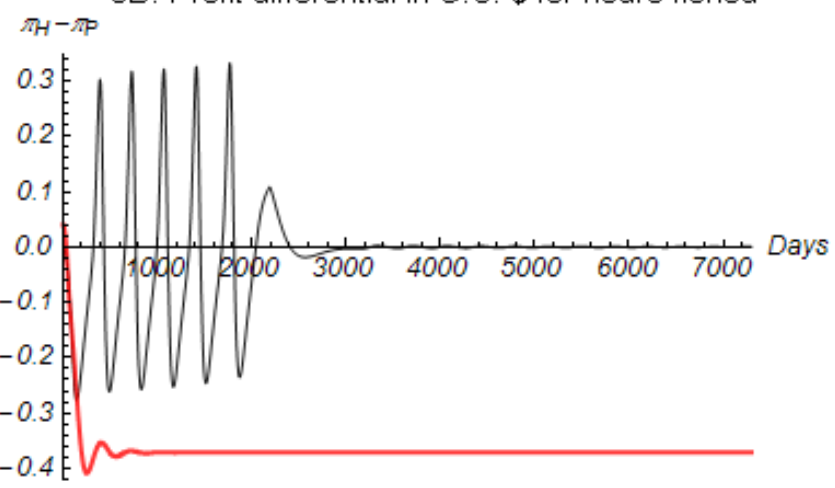

respectively. There is a trade-off between algal growth rates and the price for herbivorous fish (Fig. 10A). Recall that a price of U.S. \$3.50 flipped the system to an algae-dominated state and a complete switch to piscivore harvesting (Fig. 5A). Here, as algal growth rates decrease, the ecological system can support higher prices for herbivorous fish before the system switches. The trade-off between the overall fisher population and fishing effort for harvesting herbivores demonstrates that there is not a simple linear relationship between effort and population, as one might expect. The effects of population are much more pronounced between 1.5 and $2 \mathrm{~h} / \mathrm{d}$ of effort (Fig. 10B). Figure 10C presents a trade-off between the slope coefficient of the Hill function, i.e., the effect on coral of the transition in the community structure of algae, and fishing effort to harvest herbivores. As the effect increases, the system is able to support less fishing effort before switching to an algae-dominated state. 
Fig. 6. Simulation results reflecting changes in the price of piscivorous fish showing time-series plots for fishers (6A) and profit differentials (6D), and parametric plots for fish (6B) and for coral and algae (6C). The dots represent initial conditions.

6A. Herbivore fishers
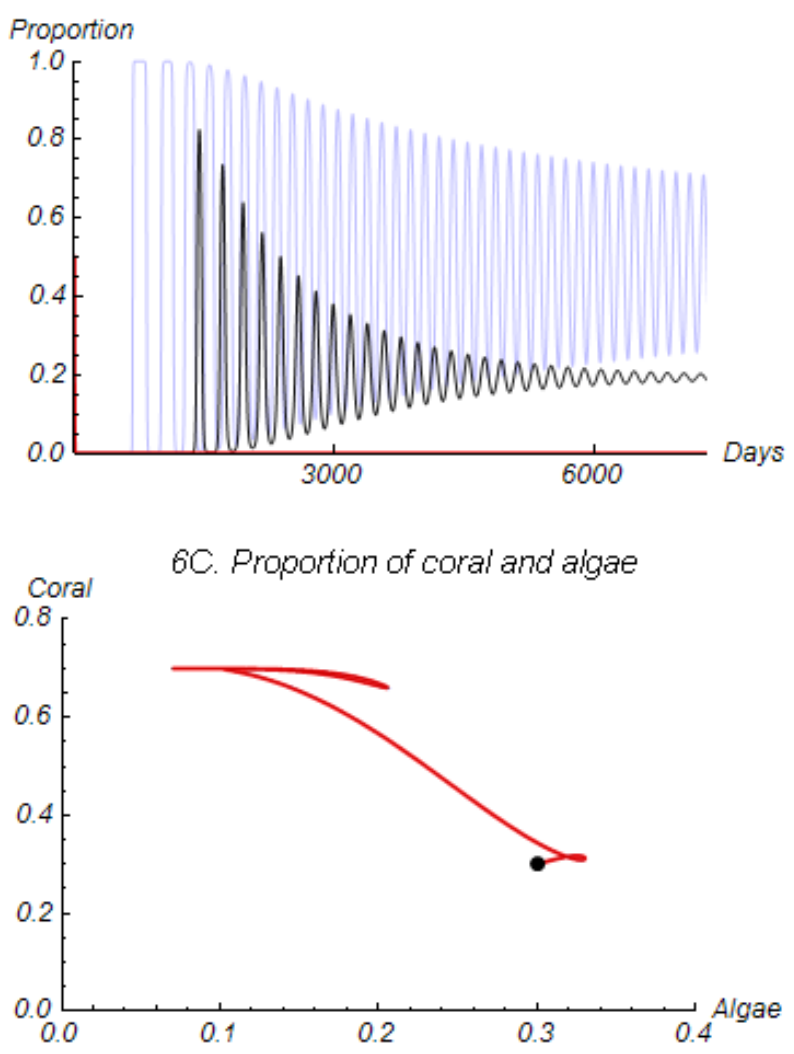

6B. Fish in kilograms per square kilometer

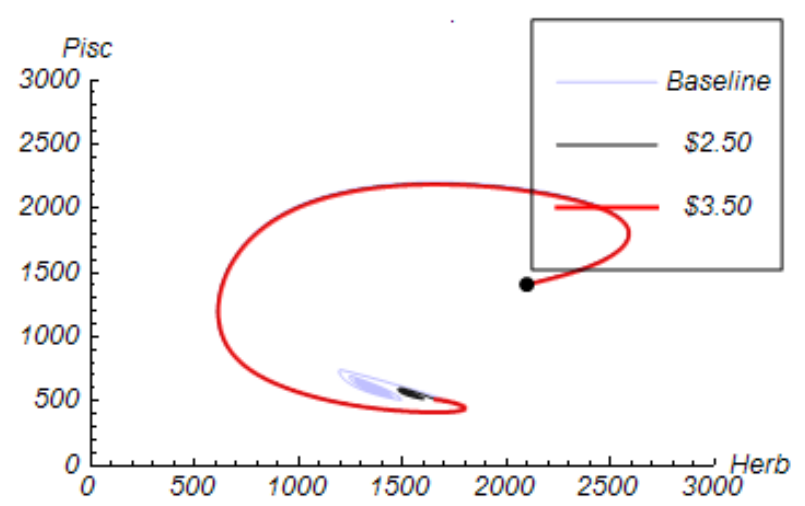

6D. Profit differential in U.S. \$ for hours fished

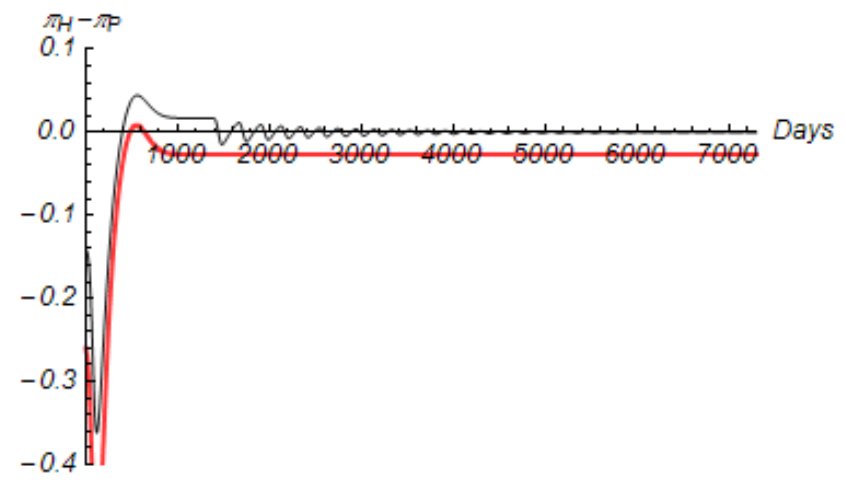

\section{DISCUSSION}

These results showed that ecosystem dynamics and stability in this stylized coral-reef ecosystem were sensitive to changes in economic, biological, and social parameters. Compared to the baseline, a loss of resilience was seen in response to increases in the price of herbivores, fishing effort to harvest herbivores, and fisher population and decreases in the speed at which profit information is disseminated within the fishing community (Figs. $11 \mathrm{~A}, \mathrm{~B})$. Increases in resilience occurred because of increases in the prices and fishing effort for piscivores. Comparing the two measures of resilience, there are few differences in the rank ordering of each sensitivity analysis with two exceptions. First, the order for the two levels of piscivore fishing effort is reversed. Alhough the basin of attraction for the coral-dominated state is greater at an effort level of 4 rather than $2 \mathrm{~h}$, the minimum Euclidean distance is less. The basin measure has intuitive appeal because it corresponds with other results that show that, as pressure on piscivores increases, resilience increases. Second, 
Fig. 7. Simulation results reflecting changes in fishers $/ \mathrm{km}^{2}$ showing time-series plots for fishers (7A) and profit differentials (7D), and parametric plots for fish (7B) and for coral and algae (7C). The dots represent initial conditions.

7A. Herbivore fishers
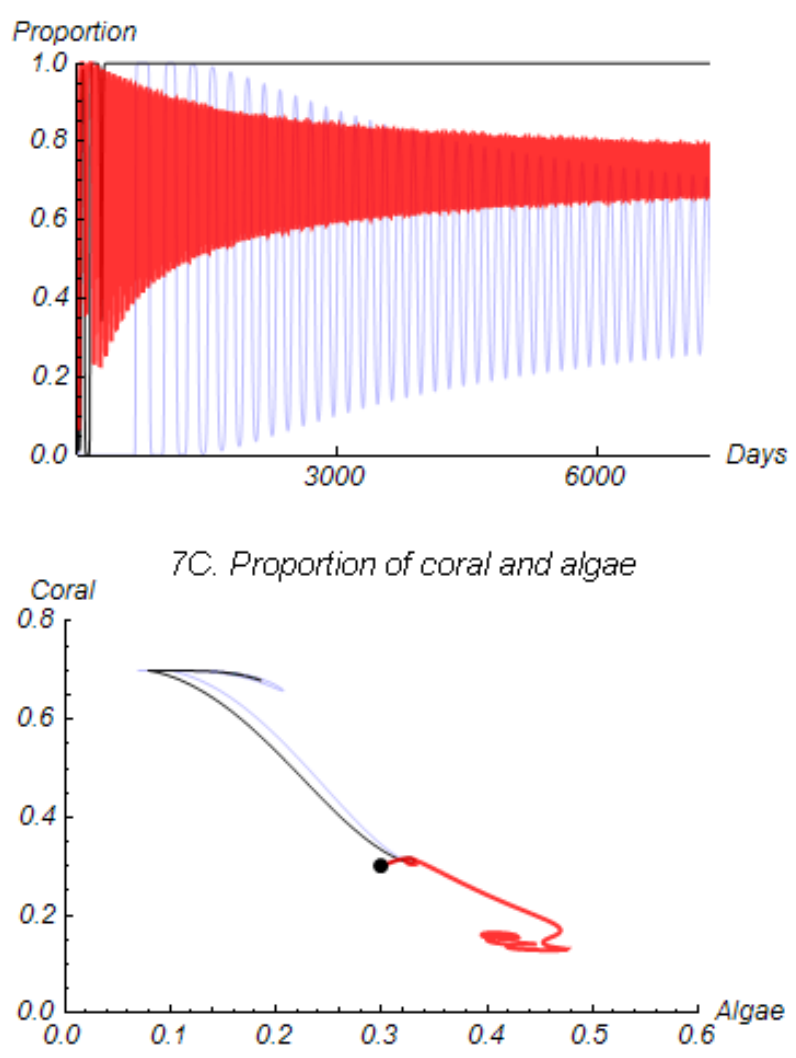

7B. Fish in kilograms per square kilometer
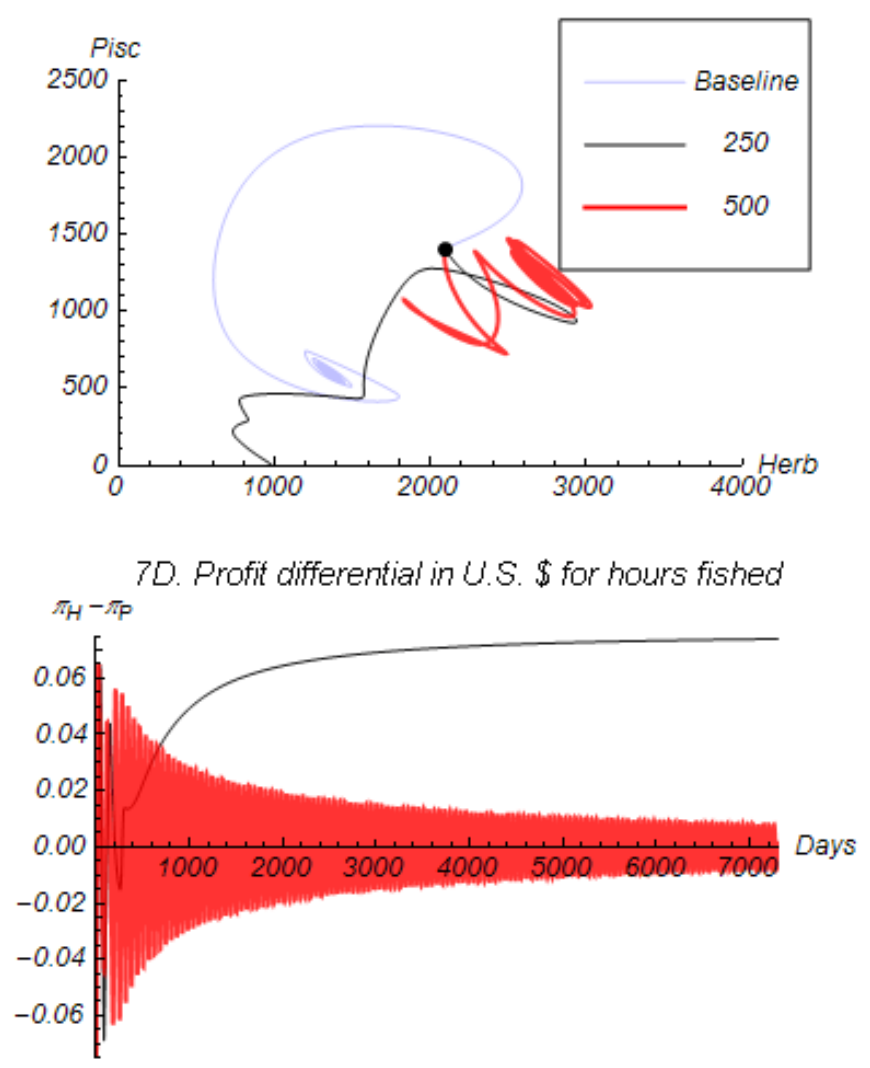

at a price of U.S. $\$ 3.50$ for herbivorous fish, the Euclidean distance is zero because the final state is algae-dominated, whereas the basin of attraction measurement is not zero, indicating that different initial conditions would lead to the coral-dominated state using identical parameters.

Increases in resilience because of increases in the prices for and effort required to harvest piscivores are easy to explain. When released from predatory pressures, herbivorous fish are able to keep the algal cover in check, maintaining the coral-dominated state. This result, however, runs contrary to the evidence of certain studies that show that predator removal can cause a switch to the algae-dominated state. McClanahan et al. (2002) found that intense harvesting of predatory trigger fish released their sea urchin prey, which led to more coral reef erosion and the replacement of corals by seagrasses. Hughes (1994) suggested that high densities of sea urchins in the Caribbean led to a disease epidemic and mass mortality in their population, resulting in a switch to a high algal cover state. The crown-of-thorns starfish (Acanthaster), a voracious coralivore, has 
Fig. 8. Simulation results reflecting changes in fisher effort $(\mathrm{h} / \mathrm{d})$ for herbivorous fish, showing timeseries plots for fishers (8A) and profit differentials (8D), and parametric plots for fish (8B) and for coral and algae (8C). The dots represent initial conditions.

8A. Herbivore fishers
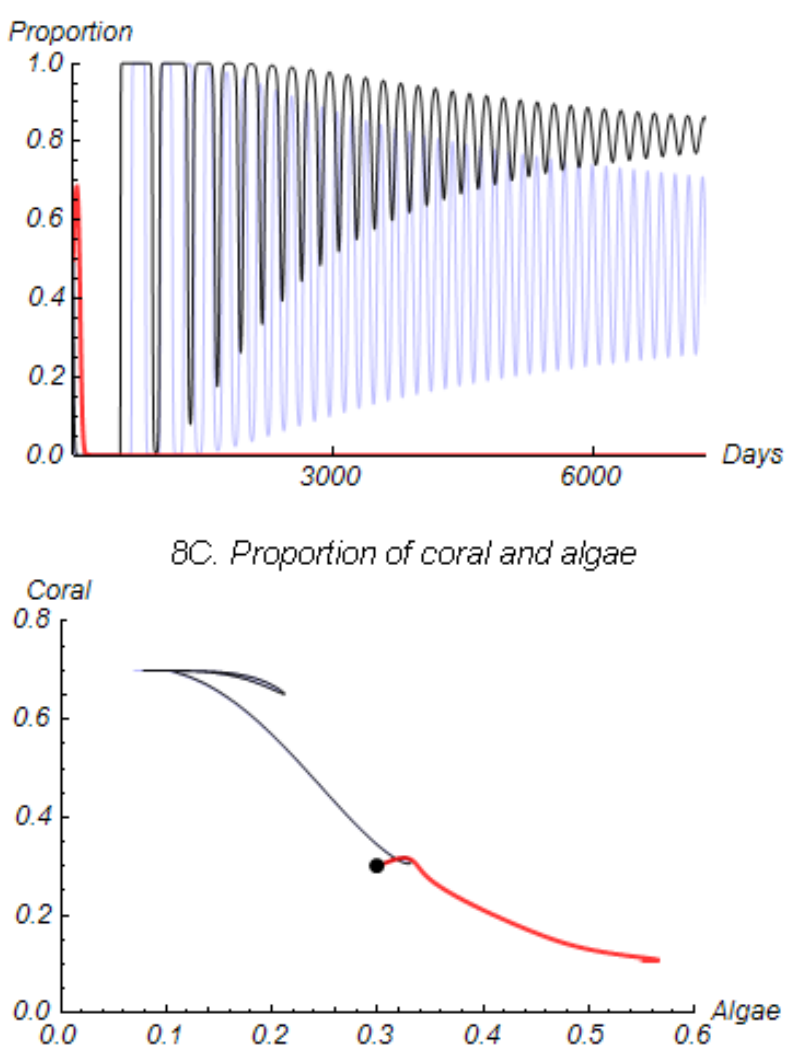

8B. Fish in kilograms per square kilometer

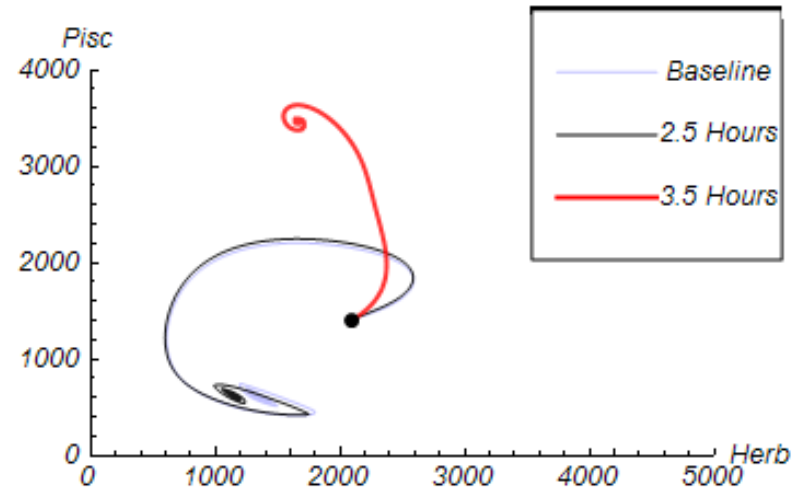

80. Profit differential in U.S. \$ for hours fished

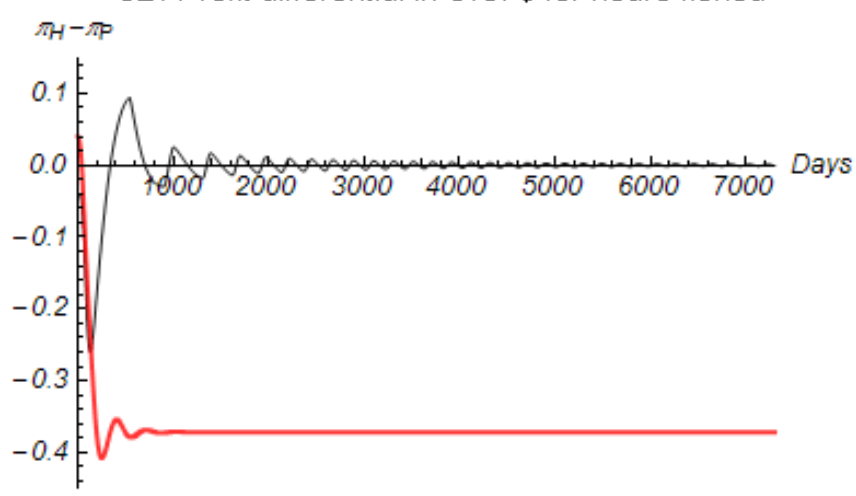

been found to reduce coral cover when predators are removed (Jackson et al. 2001, Dulvy et al. 2004). The adverse effects of piscivore removal on coral cover were not seen in this study because sea urchins and the crown-of-thorn starfish were not modeled.

System dynamics were complex. In each of the simulations, profit differentials drove the switch from one kind of fish to another. Profit differentials were driven by price, fish population densities, the differing catch efficiencies for herbivores and piscivores, coral and algae cover, and lag time.
However, there were dramatic differences in system dynamics depending on how profit levels fluctuated. For example, in the baseline simulation, after the fish, coral, and algae populations stabilized, the fisher populations continued to oscillate wildly because of small but low-frequency oscillations in profits (Fig. 3D). Because the population of fishers as a whole shifts strategies gradually as a result of profit differentials, the longer that differential is maintained, the easier it is for these populations to grow apart. On the other hand, at a price of U.S. $\$ 3.00$ for herbivores, fisher populations oscillate 
Fig. 9. Simulation results reflecting changes in the switching speed of fishers, showing time-series plots for fishers (9A) and profit differentials (9D), and parametric plots for fish (9B) and for coral and algae (9C). The dots represent initial conditions.

9A. Herbivore fishers

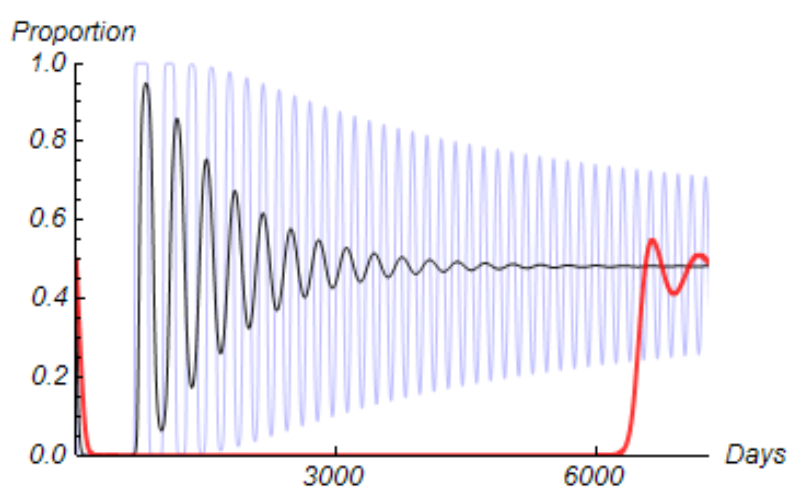

9C. Proportion of coral and algae

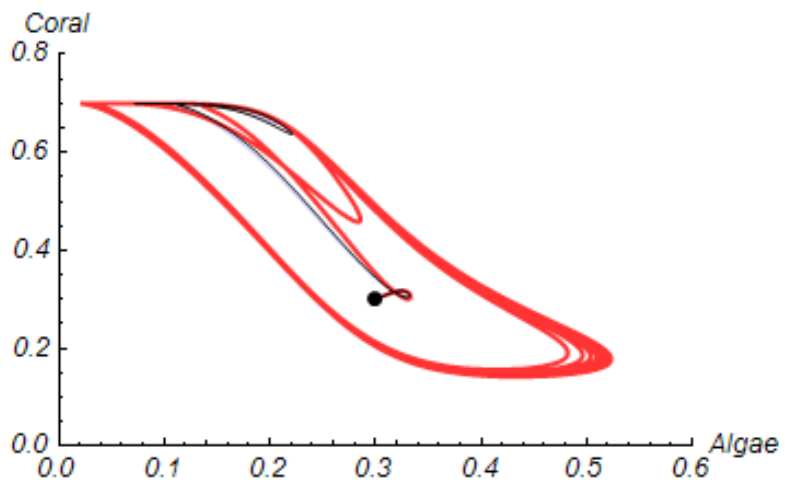

9B. Fish in kilograms per square kilometer

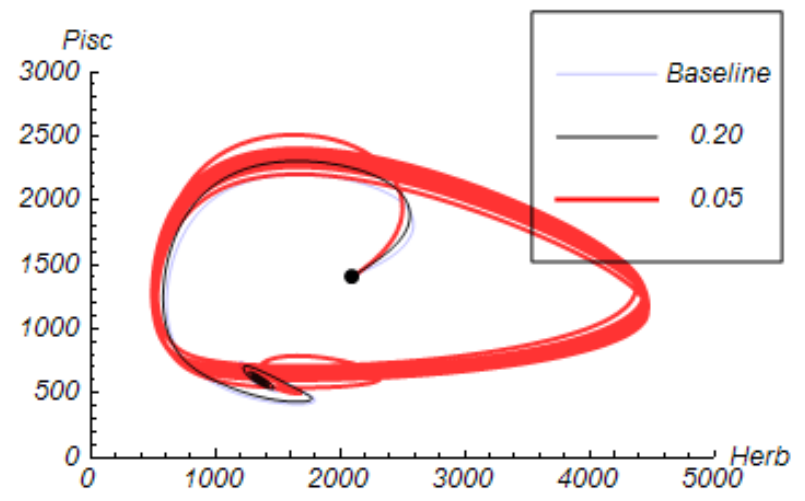

9D. Profit differential in U.S. \$ for hours fished

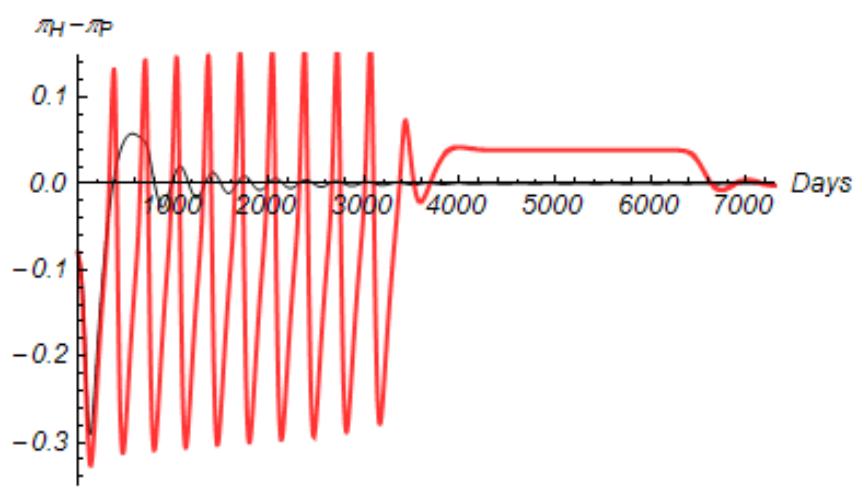

slightly because profits, although oscillating, do so at a higher frequency (Fig. 5D). Other complexity is seen in Fig. 9. At a lag time of 0.05, the proportion of herbivore harvesters increases sharply at $6000 \mathrm{~d}$ even though the profits for fishing herbivores overtakes the profits for piscivores at $3370 \mathrm{~d}$. At $6600 \mathrm{~d}$ the profit differential is small, and profits begin to oscillate. This results in slight oscillations in both populations at roughly $50 \%$.

Some results are both complex and counterintuitive. Increasing the price of herbivores from U.S. \$3.00 to U.S. $\$ 3.50$ had the effect of switching the ecosystem to an algae-dominated state. The overall system became productive enough and the piscivore population large enough that fishers chose to harvest only piscivores. The piscivores kept the herbivores in check, and the system, being very productive, kept the piscivore population high despite harvest pressures. Fishers harvested only piscivores as a result of a price increase for herbivores. It should be noted that, after taking into account the role of coral in providing complex habitat for predator evasion, spawning, settlement, and recruitment, fish 
Fig. 10. Graphical mapping of resilience thresholds resulting from variations in two parameters. Red, i.e. bottom, indicates coral-dominated stable state. Green, i.e. top, indicates algae-dominated stable state.

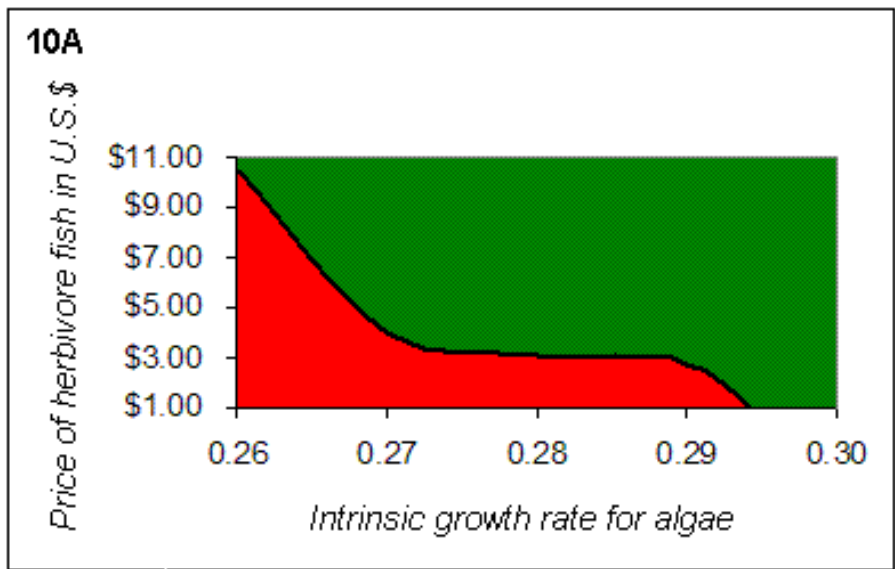

$10 \mathrm{~B}$

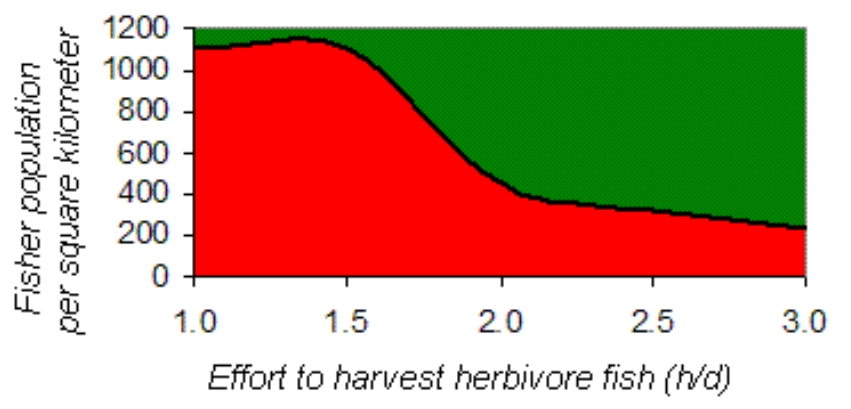

$10 \mathrm{C}$

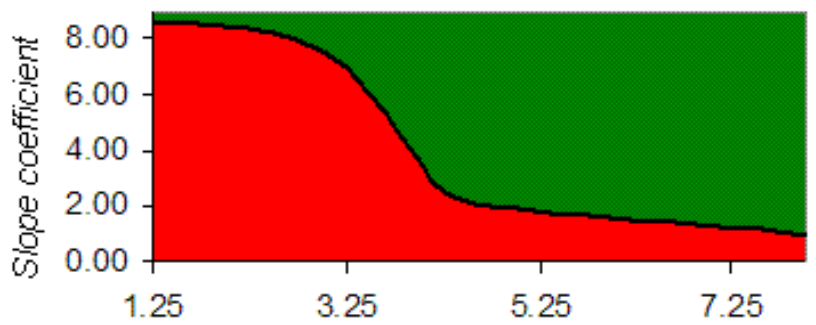

Effort to harvest herbivore fish ( $h / d)$ 
Fig. 11. Alternate measures of resilience: the proportion of the plane space of the coral/algae phase in the basin of attraction of the coral-dominated state (11A) and the minimum Euclidean distance between the coral-dominated equilibrium state and the boundary of its basin of attraction (11B). At a population of 500, there is no coral-dominated state. Instead, there is an algae-dominated state and a state characterized by stable limit cycles. In this case, the Euclidean distance is a measure from the stationary state of the stable limit cycle.

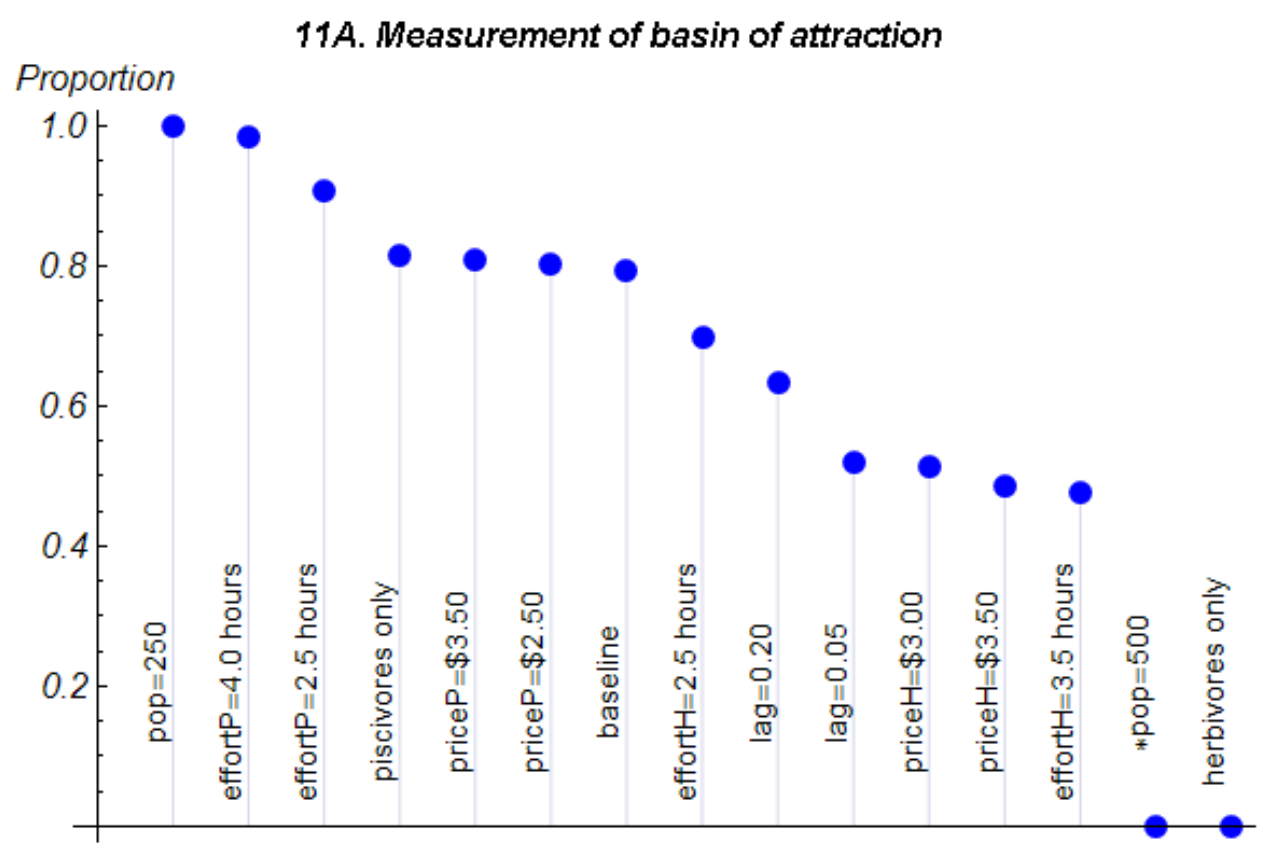

11B. Measurement of Euclidean distance

\section{Euclidean Distance}

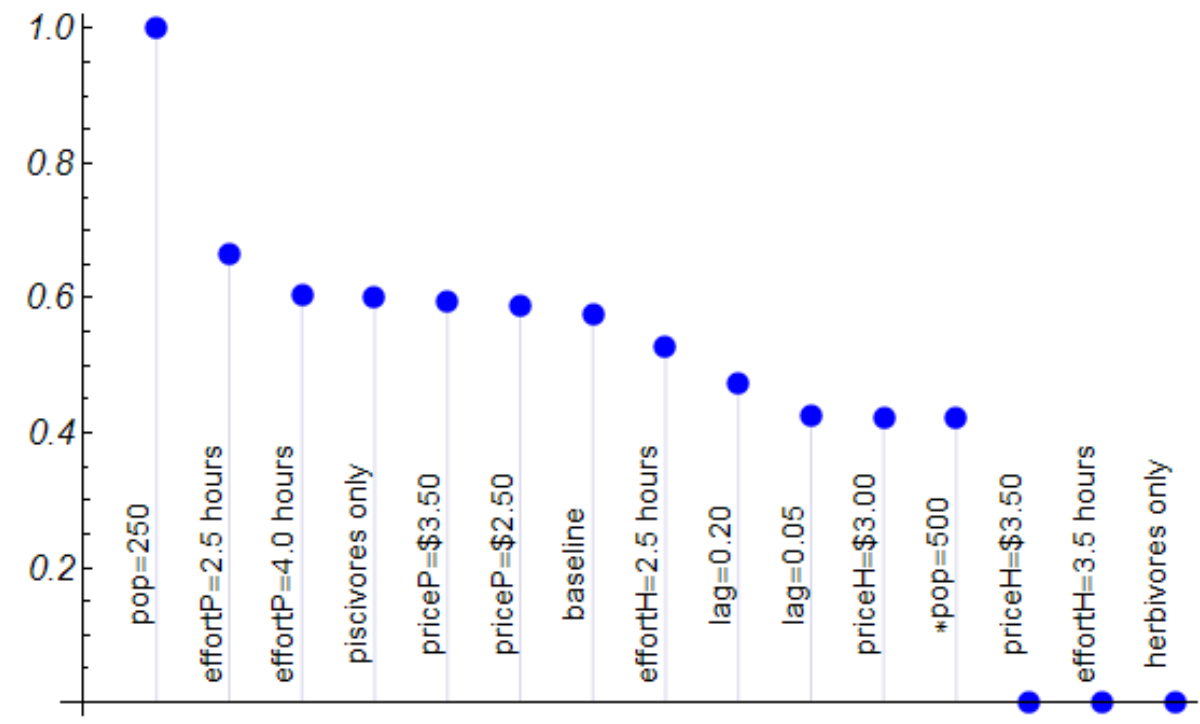


populations might ultimately do worse under a persistent algae-dominated state (Tupper and Boutilier 1997).

There is a strong nonlinear relationship between fisher density and the resilience of the coraldominated state. At the baseline density of 50 fishers $/ \mathrm{km}^{2}, 79 \%$ of the plane of the coral/algae phase was in the basin of attraction of the coraldominated state. As the density increased to 250, the entire phase plane consisted of the coraldominated attractor. At 500 fishers, the basin of attraction of the algae-dominated state began to increase. The nonlinearity is the result of adaptive harvesting. With only one type of fisher, larger fisher populations have the same effect as greater fishing effort. With adaptive harvesters, larger fisher populations make swings in the proportion of fisher types more consequential and unpredictable.

Another counterintuitive result was the persistence of predator-prey oscillations, which are not usually common under constant harvesting pressure (Strobele and Wacker 1995). As expected, facing one type of fisher, and therefore constant harvest pressure (Fig. 4), the fish populations did not fluctuate. However, in the baseline scenario (Fig. 3 ), adaptive fishermen who exerted constant harvesting pressure but shifted their efforts between fish populations maintained these oscillations for some time.

Initial conditions were important in generating different outcomes in response to parameter changes, as evidenced by the analyses of the nullclines and nullplanes (Figs. 1 and 2) and the mapping of resilience thresholds (Fig. 10). The importance of initial conditions in reef ecosystems is supported by empirical research showing that initial predator densities and fishing effort can dictate system dynamics (Dulvy et al. 2004).

\section{CONCLUSION}

This study used a simplified model of a coral reef ecosystem to explore the effects of changes in economic, biological, and social parameters in a multiple-species coral-reef ecosystem with adaptive harvesters. Several modifications are possible that might generate new or contrary results. A commonpool resource context might be analyzed by including the effects of strategic behavior. More realism might be added to the ecological model with the addition of other important functional groups such as sea urchins, coralivores, invertivores, subgroups of algae and coral, and noncommercial species. For modelers, the testing of various functional forms for species interactions might generate very different results. One might disaggregate various herbivores and piscivores to examine the effects of functional-group redundancy on ecosystem dynamics (Bellwood et al. 2004). Prices for reef fish might be determined endogenously in small subsistence fishing communities. Finally, the addition of some parameter uncertainty is likely important.

The results from this simplified model suggest that reef fisheries management should not ignore the complexity of linked ecological and social systems when formulating management plans. The components of this complexity have the potential to drive reef dynamics past undesirable thresholds. From a policy perspective, the inclusion of complexity provides new opportunities for policy innovation, expands the scope of what might be considered the purview of natural resource management, and requires new tools for evaluating policy choices and outcomes.

Trade-offs likely exist between economic, biological, and social drivers of ecosystem resilience, providing a richer array of policy alternatives to address environment problems. For example, it is well known and supported here that reducing fishing effort might prevent unfavorable ecosystem effects. However, by explicitly modeling the dynamics of coral and algae, another policy recommendation follows. Reducing algal growth rates might mitigate the adverse effects of rising prices for resources (Fig. 10). Empirical research supports this. Nutrient runoff in addition to overfishing is a particularly potent recipe for coral reef degradation because of algae overgrowth (Lapointe1997, McCook 1999). Another unusual policy innovation for resource managers might be to strengthen social networks through greater investments in information technology to increase resilience (Fig. 9). Having more policy choices makes it more likely that objectives can be met efficiently.

In addition to monitoring key species and their interactions, coral-reef resource managers need to be mindful of the social, economic, and behavioral drivers that affect coral reefs. For example, in addition to the direct threats of climate change, 
pollution, sedimentation, and overfishing, the reefs of the Pacific islands face numerous indirect economic, social, and political threats (Kramer 2008). The results presented here raise several questions. How do fishers behave when confronted with fluctuating fish stocks, changing prices, and competing strategies? How is fishing information transmitted in reef communities? How might social networks affect resource use? How do species interactions vary over time and space? What institutions affect fisher behavior? Expanding the scope of what we consider resource management and building linkages with economic and social organizations allow us to begin answering these questions.

Finally, understanding and responding to complexity in social and natural systems requires new methods of evaluating policy choices, outcomes, and biological, economic, and social trade-offs. With more experimentation, greater ecological understanding, and the study of a variety of social-ecological systems, the ranking of system states under different conditions in terms of their resilience presents the possibility of developing biological, economic, and social indicators of low resilience. This study also presented the approach of mapping resilience thresholds in twodimensional space, which might usefully be expanded to higher dimensions. The mapping of resilience thresholds in terms of key system parameters may help managers to avoid major state shifts in ecosystems; to understand the relationships between seemingly disparate economic, biological, and social drivers; and to begin weighing policy choices in terms of their effects on ecological resilience.

Responses to this article can be read online at:

http://www.ecologyandsociety.org/voll3/iss 1/art17/responses/

\section{Acknowledgments:}

The suggestions from two very helpful anonymous reviewers and the journal's editor are gratefully acknowledged. All errors and omissions are the author's responsibility.

\section{LITERATURE CITED}

Allen, C. R., L. Gunderson, and A. R. Johnson. 2005. The use of discontinuities and functional groups to assess relative resilience in complex systems. Ecosystems 8:958-966.

Anderies, J. M. 2000. On modeling human behavior and institutions in simple ecological economic systems. Ecological Economics 35:393-412.

Anderies, J. M., M. A. Janssen, and B. H. Walker. 2002. Grazing management, resilience, and the dynamics of fire-driven rangeland system. Ecosystems 5:23-44.

Atkinson, M. J., and R. W. Grigg. 1984. Model of a coral reef ecosystem II: gross and net benthic primary production at French Frigate Shoals, Hawaii. Coral Reefs 3:13-22.

Bellwood, D. R., T. P. Hughes, C. Folke, and J. Nystrom. 2004. Confronting the coral reef crisis. Nature 429:827-833.

Berner, T. 1990. Coral reef algae. Pages 253-264 in Z. Dubninsky, editor. Ecosystems of the world. Elsevier, Amsterdam, The Netherlands.

Brander, J. A., and S. M. Taylor. 1998. The simple economics of Easter Island: a Ricardo-Malthus model of renewable resource use. American Economic Review 88:119-138.

Clark, C. W. 1990. Mathematical bioeconomics: the optimal management of renewable resources. John Wiley, New York, New York, USA.

Connell, J. H., T. P. Hughes, and C. C. Wallace. 1997. A 30-year study of coral abundance, recruitment, and disturbance at several scales in space and time. Ecological Monographs 67:461-488.

Dalzell, P. 1996. Catch rates, selectivity and yields of reef fishing. Pages 161-192 in N.V.C. Poulinin and C.M. Roberts, editors. Reeffisheries. Chapman and Hall, London, UK.

Done, T. J. 1992. Phase shifts in coral reef communities and their ecological significance. Hydrobiologica 247:121-132.

Dulvy, N. K., R. P. Freckleton, and N. V. C. Polunin. 2004. Coral reef cascades and the indirect 
effects of predator removal by exploitation. Ecology Letters 7:410-416.

Edmunds, P. J., and P. S. Davies. 1986. An energy budget for Porites porites (Scleractinia). Marine Biology 92:339-347.

Finnoff, D., and J. Tschirhart. 2003a. Harvesting in an eight-species ecosystem. Journal of Environmental Economics and Management 45:589-611.

Finnoff, D., and J. Tschirhart. 2003b. Protecting an endangered species while harvesting its prey in a general equilibrium ecosystem model. Land Economics 79:160-180.

Gislason, H., M. Sinclair, K. Sainsbury, and R. O'Boyle. 2002. Symposium overview: incorporating ecosystem objectives within fisheries management. Journal of Marine Science 57:468-475.

Gordon, H. S. 1954. The economic theory of a common property resource: the fishery. Journal of Political Economy 62:124-142.

Hawkins, J. P., and C. M. Roberts. 2004. Effects of artisanal fishing on Caribbean coral reefs. Conservation Biology 18:215-226.

Hotelling, H. 1931. The economics of exhaustible resources. Journal of Political Economy 39:137-175.

Hughes, T. P. 1994. Catastrophes, phase shifts, and large-scale degradation of a Caribbean coral reef. Science 265:1547-1551.

Hughes, T. P., D. C. Reed, and M. J. Boyle. 1987. Herbivory on coral reefs: community structure following mass mortality of sea urchins. Journal of Experimental Marine Biology \& Ecology 113:39-59.

Jackson, J. B. C., M. X. Kirby, W. H. Berger, K. A. Bjorndal, L. W. Botsford, B. J. Bourque, R. H. Bradbury, R. Cooke, J. Erlandson, J. A. Estes, T. P. Hughes, S. Kidwell, C. B. Lange, H. S. Lenihan, J. M. Pandolfi, C. H. Peterson, R. S. Steneck, M. J. Tegner, and R. R. Warner. 2001. Historical overfishing and the recent collapse of coastal ecosystems. Science 301:929-933.

Jager, W., M. A. Janssen, H. J. M. De Vries, J. De Greef, and C. J. A. Vlek. 2000. Behaviour in commons dilemmas: Homo economicus and Homo psychologicus in an ecological-economic model. Ecological Economics 35:357-379.

Jennings, S., and N. V. C. Polunin. 1996. Effects of fishing effort and catch rate upon the structure and biomass of Fijian reef fish communities. Journal of Applied Ecology 33:400-412.

Jennings, S., and N. V. C. Polunin. 1997. Impacts of predator depletion by fishing on the biomass and diversity of non-target reef fish communities. Coral Reefs 16:71-82.

Kahneman, D., and A. Tversky. 1979. Prospect theory: an analysis of decision under risk. Econometrica 47: 263-291.

Kramer, D. B. 2008. Resilient reef fisheries governance of the Pacific Islands in the era of globalization. In W. W. Taylor, N. J. Leonard, and M. G. Schechter, editors. International governance of fisheries ecosystems: learning from the past, finding solutions for the future. American Fisheries Society, Bethesda, Maryland, USA, in press.

Lapointe, B. E. 1997. Nutrient thresholds for bottom up control of macroalgal blooms on coral reefs in Jamaica and southeast Florida. Limnology and Oceanography 42:1119-1131.

Lewis, J. B. 1981. Estimates of secondary production of reef corals. Pages 369-373 in D. L. Taylor, editor. Proceedings of the 4th International Coral Reef Symposium 2. University of the Philippines, Manila, The Philippines.

Lirman, D. 2001. Competition between macroalgae and corals: effects of herbivore exclusion and increased algal biomass on coral survivorship and growth. Coral Reefs 19:392-399.

May, R., J. R. Beddington, C. W. Clark, S. J. Holt, and R. M. Laws. 1979. Management of multispecies fisheries. Science 205:267-277.

McClanahan, T. R. 1992. Resource utilization, competition and predation: a model and example from coral reef grazers. Ecological Modelling 61:195-215.

McClanahan, T. R. 1995. A coral reef ecosystemfisheries model: impacts of fishing intensity and catch selection on reef structure and processes. 
Ecological Modelling 80:1-19.

McClanahan, T. R., A. T. Kamukuru, N. A. Muthiga, M. Yebio, M. Gilagabher, and D. Obura. 1996. Effect of sea urchin reductions on algae, coral, and fish populations. Conservation Biology 10:136-154.

McClanahan, T. R., N. Polunin, and T. Done. 2002. Ecological states and the resilience of coral reefs. Conservation Ecology 6(2): 18. [online] URL: http://www.consecol.org/vol6/iss2/art18/.

McCook, L. J. 1999. macro-algae, nutrients and phase shifts on coral reefs: scientific issues and management consequences for the Great Barrier Reef. Coral Reefs 18:357-367.

McCook, L. J., J. Jompa, and G. Diaz-Pulido. 2001. Competition between corals and algae on coral reefs: a review of evidence and mechanisms. Coral Reefs 19:400-417.

Miller, M. W., M. E. Hay, S. L. Miller, D. Malone, E. E. Sotka, and A. M. Szmant. 1999. Effects of nutrients versus herbivores on reef algae: a new method for manipulating nutrients on coral reefs. Limnology and Oceanography 44:1847-1861.

Myers, R. A., and B. Worm. 2003. Rapid worldwide depletion of predatory fish communities. Nature 423:280-283.

Nugues, M. M., G. W. Smith, R. J. Hooidonk, M. I. Seabra, and R. P. M. Bak. 2004. Algal contact as a trigger for coral disease. Ecology Letters 7: 919-923.

Odum, H. T., and E. P. Odum. 1955. Trophic structure and productivity of a windward coral reef community on Eniwetok Atoll. Ecological Monographs 25:291-320.

Ostrander, G. K., K. M. Armstrong, E. T. Knobbe, D. Gerace, and E. P. Scully. 2000. Rapid transition in the structure of a coral reef community: the effects of coral bleaching and physical disturbance. Proceedings of the National Academy of Sciences of the United States 97:5297-5302.

Pikitch, E. K., C. Santora, E. A. Babcock, A. Bakun, R. Bonfil, D. O. Conover, P. Dayton, P. Doukakis, D. Fluharty, B. Heneman, E. D. Houde, J. Link, P. A. Livingston, M. Mangel, M.
K. McAllister, J. Pope, and K. J. Sainsbury. 2004. Ecosystem-based fishery management. Science 305:346-347.

Polovina, J. J. 1988. Model of a coral reef ecosystem I: the ECOPATH model and its applications to French Frigate Shoals. Coral Reefs 3:1-12.

Polunin, N. V. C. 1996. Trophodynamics of reef fisheries productivity. Pages 113-136 in N. V. C. Polunin and C. M. Roberts, editors. Reef Fisheries. Chapman and Hall, London, UK.

Polunin, N. V. C., and D. W. Klump. 1989. Ecological correlates of foraging periodicity in herbivorous reef fishes of the Coral Sea. Journal of Experimental Marine Biology and Ecology 126:1-20.

Roberts, C. M., C. J. McClean, J. E. N. Veron, J. P. Hawkins, G. R. Allen, D. E. McAllister, C. G. Mittermeier, F. W. Schueler, M. Spalding, F. Wells, C. Vynne, and T. B. Werner. 2002. Marine biodiversity hotspots and conservation priorities for tropical reefs. Science 295:1280-1284.

Scheffer, M., S. Carpenter, J. A. Foley, C. Folke, and B. Walker. 2001. Catastrophic shifts in ecosystems. Nature 413:591-596.

Scott, A. 1955. The fishery: the objective of sole ownership. Journal of Political Economy 63:116-124.

Sethi, R., and E. Somanathan. 1996. The evolution of social norms in common property resource use. American Economic Review 86:766-788.

Simon, H. A. 1955. A behavioral model of rational choice. Quarterly Journal of Economics 69:99-118.

Stow, C., C. R. Allen, and A. S. Garmestani. 2007. Evaluating discontinuities in complex systems: toward quantitative measures of resilience. Ecology and Society 12(1): 26. [online] URL: http://www.e cologyandsociety.org/vol12/iss1/art26/.

Strobele, W., and H. Wacker. 1995. The economics of harvesting predator-prey systems. Journal of Economics 61:65-81.

Tanner, J. E. 1995. Competition between 
scleractinian corals and macro-algae: an experimental investigation of coral growth, survival and reproduction. Journal of Experimental Marine Biology and Ecology 2:151-168.

Taylor, P. D., and L. B. Jonker. 1978. Evolutionary stable strategies and game dynamics. Mathematical Biosciences 40:

Tupper, M., and R. G. Boutilier. 1997. Effects of habitat on settlement, growth, predation risk and survival of a temperate reef fish. Marine EcologyProgress Series 151:225-236.

Van Den Bergh, J. C. J. M., A. Ferrer-ICarbonell, and G. Munda. 2000. Alternative models of individual behaviour and implications for environmental policy. Ecological Economics 32:43-61.

Wanders, J. B. W. 1976. The role of benthic algae in the shallow reef of Curacao (Netherlands Antilles): primary productivity in the coral reef. Aquatic Botany 2:235-270.

Wilen, J. E. 2000. Renewable resource economists and policy: What differences have we made? Journal of Environmental Economics and Management 39:306-327.

Williams, I. D., and N. V. C. Polunin. 2001. Largescale associations between macroalgal cover and grazer biomass on mid-depth reefs in the Caribbean. Coral Reefs 19:358-366. 